INTERNATIONAL MONETARY FUND

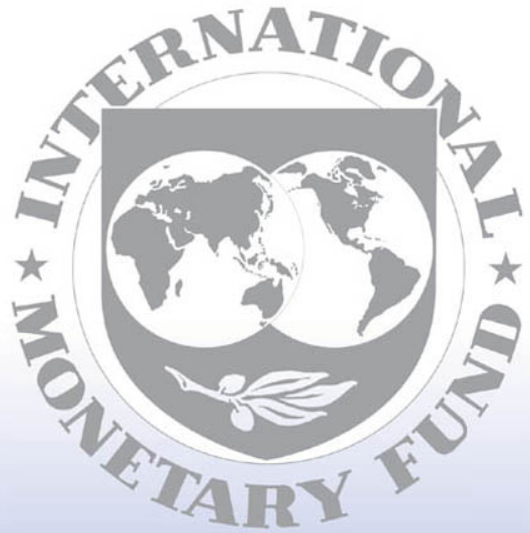

Staff

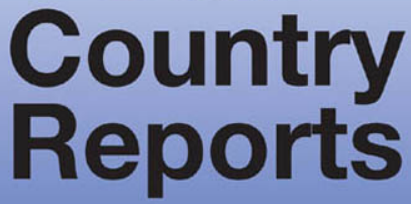




\section{Republic of Armenia: Selected Issues}

This Selected Issues paper for the Republic of Armenia was prepared by a staff team of the International Monetary Fund as background documentation for the periodic consultation with the member country. It is based on the information available at the time it was completed on October 31 , 2008. The views expressed in this document are those of the staff team and do not necessarily reflect the views of the Government of the Republic of Armenia or the Executive Board of the IMF.

The policy of publication of staff reports and other documents by the IMF allows for the deletion of market-sensitive information.

Copies of this report are available to the public from

International Monetary Fund • Publication Services

700 19th Street, N.W. • Washington, D.C. 20431

Telephone: (202) 623-7430 • Telefax: (202) 623-7201

E-mail: publications@imf.org • Internet: http://www.imf.org

Price: $\$ 18.00$ a copy

\section{International Monetary Fund Washington, D.C.}


This page intentionally left blank 


\section{INTERNATIONAL MONETARY FUND}

\section{REPUBLIC OF ARMENIA}

\section{Selected Issues}

Prepared by Borja Gracia (FAD), Holger Floerkemeier (MCD), Reginald Darius (SPR)

Approved by Middle East and Central Asia Department

October 31, 2008

Contents

Executive Summary

I. Enhancing Fiscal Policy in Armenia ...............................................................

A. Background ......................................................................................

B. The Importance of a Consistent Fiscal Framework ……..................................

Measuring the Fiscal Stance ...........................................................................

Determining the Impact of Fiscal Policy: the "Fiscal Impulse"......................... 1

Estimating a Cyclically-Adjusted Fiscal Balance …………..............................11

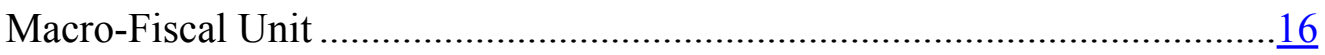

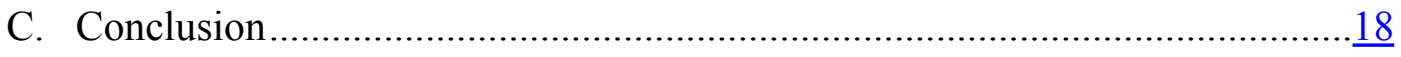

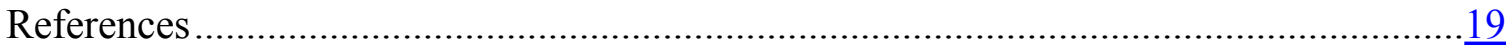

II. Smoothing Exchange Rate or Fuelling Inflation: What are the Effects of Foreign Exchange Market Intervention in Armenia? ..........................................................20

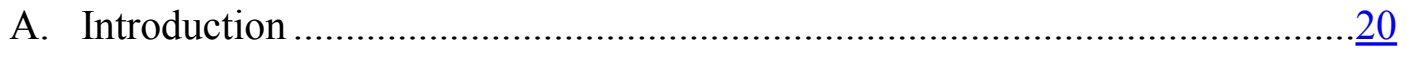

B. Foreign Exchange Market Trends and Intervention Policies..............................23

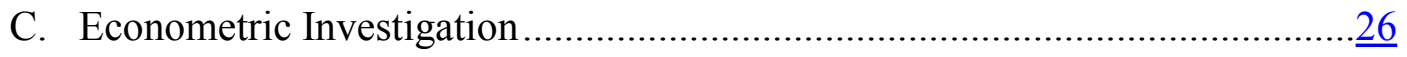

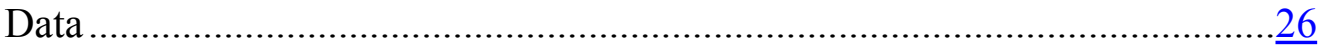

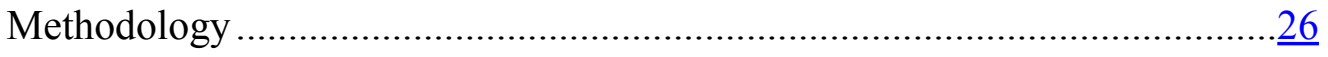

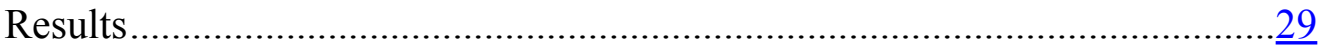

D. Consistency of Exchange Rate and Monetary Policies ......................................34

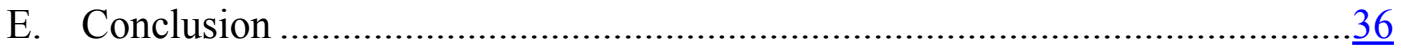

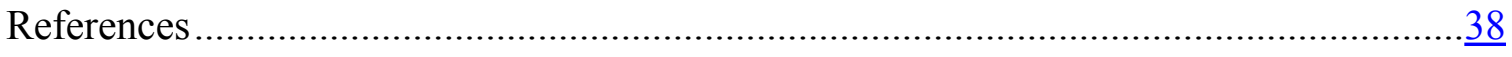

III. Exchange Rate Appreciation and External Competitiveness in Armenia ................. $\underline{40}$

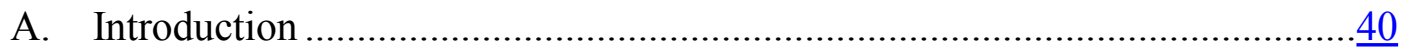


B. Recent External Developments .......................................................

C. Exchange Rate Assessment............................................................... 43

Purchasing Power Parity (PPP) Approach ............................................. 43

Behavioral Equilibrium Real Exchange Rate (BEER) Approach................... 45

External Sustainability (ES) Approach ................................................. 47

Macroeconomic Balance (MB) Approach ............................................... 47

D. Exchange Rate Pass-Through and Domestic Competition ............................48

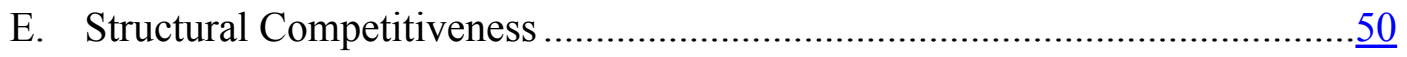

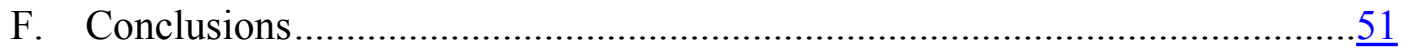

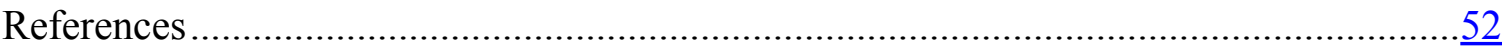

Figures

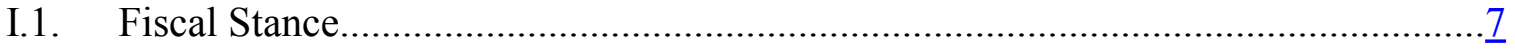

I.2. Government Spending Shock ...................................................................

I.3. Labor Market Response to a Government Spending Shock .................................. 9

I.4. Response of Economic Activity to a Government Spending Shock .....................10

I.5. Potential Output (Annual Data) .................................................................

I.6. Potential Output (Annualized Quarterly Data).................................................

I.7. Cyclical Adjustment to Tax Revenues .........................................................13

I.8. Cyclical Adjustment to Government Spending .............................................. 14

I.9. Cyclically Adjusted Underlying Fiscal Balance ............................................

I.10. Cyclical Adjustment to Underlying Fiscal Balance ...................................... 15

I.11. Fiscal Stance Revisited .........................................................................

II.1. Exchange Rate and Foreign Exchange Market Intervention ................................

II.2. Foreign Exchange Market Characteristics ....................................................

II.3. Financial Dedollarization and Cash Dollar Holdings .....................................

II.4. Intervention, Money Growth, and Inflation ............................................ $\frac{35}{41}$

III.1. Net Investment Position ......................................................................... 41

III.2. External Balance ................................................................................ 41

III.3. REER and NEER (1995-2007) ............................................................... 42

III.4. Unit Labor Costs: Average Annual Wage Bill/Nominal GDP............................ 43

III.5. Local Price Level Relative to U.S. Price Level............................................... 44

III.6. Relative Price Levels and Relative Incomes (2004) .........................................44

III.7. Equilibrium and Actual Real Exchange Rate (PPP Approach) ........................... 45

III.8. Actual and Estimated Equilibrium REER (Equation 1)..................................... 46

III.9. Impulse Responses of Import Prices to NEER Shocks …..................................

III.10. Exchange Rate Pass-Through to Import Prices ................................................ 49

III.11. Speed of Exchange Rate Pass-Through to Import Prices.................................... $\underline{50}$

Tables

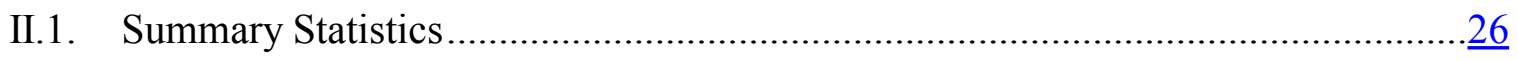


II.2. Determinants of CBA Foreign Exchange Intervention ……………………….....

II.3. Impact of CBA Intervention on the Level of the Exchange Rate.............................31

II.4. Impact of CBA Intervention on Deviations from Exchange Rate Trend .................33

III.1. Selected Countries Rankings in the Business Environment Database (2006-08) ...50

III.2. Global Competitiveness Index Ranking and Score, 2007-08 ...............................51 


\section{EXECUTIVE SUMMARY}

This Selected Issues Paper provides additional background information and analysis to support the discussion in the Staff Report.

\section{Chapter I: Enhancing Fiscal Policy in Armenia}

Building up fiscal space during economic expansions is key for the effective implementation of stimulatory policies during downturns. Following a period of significant fiscal consolidation, Armenia's underlying fiscal balance started to deteriorate in 2004 - at a time of rapid economic growth. The chapter jumpstarts the discussion of the role of fiscal policy as an effective demand management tool. The analysis covers the impact of fiscal policy on aggregate demand (focusing on calculations of the fiscal impulse) and on aggregate supply (focusing on calculations of the cyclically-adjusted fiscal balance).

\section{Chapter II: Smoothing Exchange Rate or Fuelling Inflation: What are the Effects of Foreign Exchange market Intervention in Armenia?}

The Armenian dram has appreciated considerably over the past six years, driven by strong foreign exchange inflows. Reflecting both the persistent appreciation pressures and heightened market volatility, foreign exchange market interventions by the central bank have increased substantially. The chapter analyzes the impact of central bank interventions from 2001 to 2008. The focus is on investigating the effectiveness of intervention in moderating the extent and volatility of exchange rate changes. The chapter also discusses trade-offs between inflation targeting and exchange rate policy objectives, and possible inconsistencies between the monetary and intervention policies followed in the recent past.

\section{Chapter III: Exchange Rate Appreciation and External Competitiveness in Armenia}

The chapter's assessment of Armenia's exchange rate suggests that the recent dramatic appreciation of the dram has removed any previous undervaluation, bringing the real exchange rate near or possibly slightly above equilibrium. Meanwhile, pass-through estimates show significant downward rigidity in import prices in response to exchange rate movements. The current account deficit has worsened sharply during the past couple of years, raising concerns about external sustainability. Although risks of a disruptive external correction remain modest, there is need to strengthen competitiveness through accelerated structural reforms in order to reduce medium term vulnerabilities. 


\section{Enhancing Fiscal Policy in Armenia ${ }^{1}$}

\section{A. Background}

1. Armenia's chronic low tax revenue has dominated the fiscal policy debate during the last decade. This issue is still relevant today: notwithstanding recent improvements in tax collection, Armenia's tax revenue remains one of the lowest in the region, and significantly below potential. At the same time, there is clear consensus on the key elements of a reform of the tax system. Following intensive technical assistance, the IMF, WB, and USAID have consistently argued that, unless significant structural change takes place, further improvements in tax collection are unlikely, and recent ones are not sustainable. In particular, there is a clear need to upgrade the structure and business processes of the tax and customs administrations, and to address current deficiencies in tax policy (absence of a VAT threshold, a "simplified" regime that is difficult to administer and comply with, and presumptive regimes that are, in reality, privileged regimes). Recent legislative changes introducing a VAT threshold and a simplified regime for those businesses below the threshold, as well as the adoption of a comprehensive and ambitious modernization plan for revamping tax administration, are promising steps in the right direction.

2. The policy debate now should shift focus to the role of fiscal policy as an effective demand management tool. Armenia's rising income level and increasing integration in global markets, together with the limited effectiveness of monetary policy, call for a more active stabilization role for fiscal policy. Against this background, policy discussions should concentrate on the effect of fiscal policy on aggregate demand (including the price level, exchange rate, and the external current account) and aggregate supply (including cyclical effects of revenues and expenditures). The objective of this note is to initiate this discussion.

\section{B. The Importance of a Consistent Fiscal Framework}

3. In many transition countries, it has proven difficult to implement consistent fiscal policies with a medium-term perspective. The lack of formal analysis linking short-term decisions with their medium-term costs implications tends to lead policymakers to accommodate pressures to relax the fiscal position, without taking into consideration intertemporal policy alternatives. Moreover, shortsighted fiscal policies often ignore 'contingent' or implicit public liabilities, although they pose a fiscal risk and, therefore, should be part of the policy-making process.

\footnotetext{
${ }^{1}$ Prepared by Borja Gracia.
} 
4. The effectiveness of economic policy depends critically on well-established, transparent, and clear frameworks. Not only should policies be sound and based on solid analysis, but they also need to be predictable. Furthermore, the monetary and fiscal policy frameworks should be consistent and based on common, well publicized, long-term objectives in order to increase policy credibility and effectiveness, and help anchor expectations. In the case of Armenia, this means that the fiscal policy framework needs to be aligned with the existing inflation-targeting regime, and keep up with increasingly sophisticated financial markets. Importantly, under the current circumstances, it has to support monetary policy in dealing with a challenging international economic environment.

5. The current fiscal framework consists of a three-year medium-term expenditure framework (MTEF), where priorities and expenditure envelopes are established, complemented by a debt management law that has some of the ingredients of a fiscal responsibility law. These include the establishment of a ceiling on public debt at 60 percent of GDP and some constraints on the overall balance when debt is above 50 percent of GDP. The framework has been weakened by major policy decisions taken outside the MTEF, with permanent, long-term implications on fiscal sustainability, such as the recent large increase in average pensions.

6. Public debt is low, posing no short-term risk to fiscal sustainability. In this context, it is difficult to anchor short-term fiscal policy to long-term fiscal sustainability. In any event, medium-term fiscal risks should be routinely assessed and discussed in budget documents, and their impact on long-term fiscal sustainability should be quantified. On the other hand, recent hikes in energy and food prices, and the potential serious economic downturn resulting from the international financial crisis, have highlighted the need for a more pro-active fiscal policy. This requires a clear understanding of the impact of fiscal policy on key macroeconomic variables, such as growth and inflation. ${ }^{2}$

\section{Measuring the fiscal stance}

7. Obtaining an accurate measure of the fiscal stance is key to designing sound economic policies. In the case of Armenia, such a measure that accurately reflects the impact of government spending on domestic demand could be the underlying fiscal balancedefined as the overall balance excluding grants and external interest payments and including all subsidies (i.e., the gas subsidy that existed until May 2008). In principle, coverage should be as wide as possible, including not only the central government, but also the state fund for social insurance (recently consolidated into the central government budget), local governments, state-owned enterprises, and off-budgetary accounts. Ideally, government

\footnotetext{
${ }^{2}$ For a comprehensive discussion of the potential of fiscal policy as a demand management tool, including a survey of literature, see WEO (October 2008), Chapter 5, "Fiscal Policy as a Countercyclical Tool."
} 
spending directed to imports should also be excluded from this measure, but this is technically difficult.

8. Different measures of the fiscal stance lead to different policy diagnostics and prescriptions (Figure I.1). An inaccurate measure of the fiscal stance could be misleading. For example, based on the overall balance, as defined in the 2005-08 PRGF-supported program (very closely related to budget definitions), there was a drastic fiscal adjustment during 19992002, with a moderate deterioration of the fiscal position until 2005, and a slight improvement thereafter. But using the underlying balance, the fiscal adjustment seems less drastic and spread over a longer period (1999-2004). More importantly, and contrary to what the overall balance suggests, the underlying balance points to a steady deterioration of the fiscal stance during the last three years. Large grant disbursements in 2002 and 2003 explain the initial discrepancy, and the off-budget gas subsidy introduced in 2006 explains the more recent gap. Although the gas subsidy has ultimately financed imports, effectively it was a direct transfer to residents and businesses in Armenia that affected their disposable income, and thus directly impacted domestic aggregate demand much the same way as any increase in spending intended to offset a negative external shock. Therefore, any meaningful measure of the fiscal stance must include the gas subsidy. A third measure of the fiscal stance, taking into account cyclical factors (the cyclically adjusted balance) will be discussed below.

Figure I.1. Armenia: Fiscal Stance

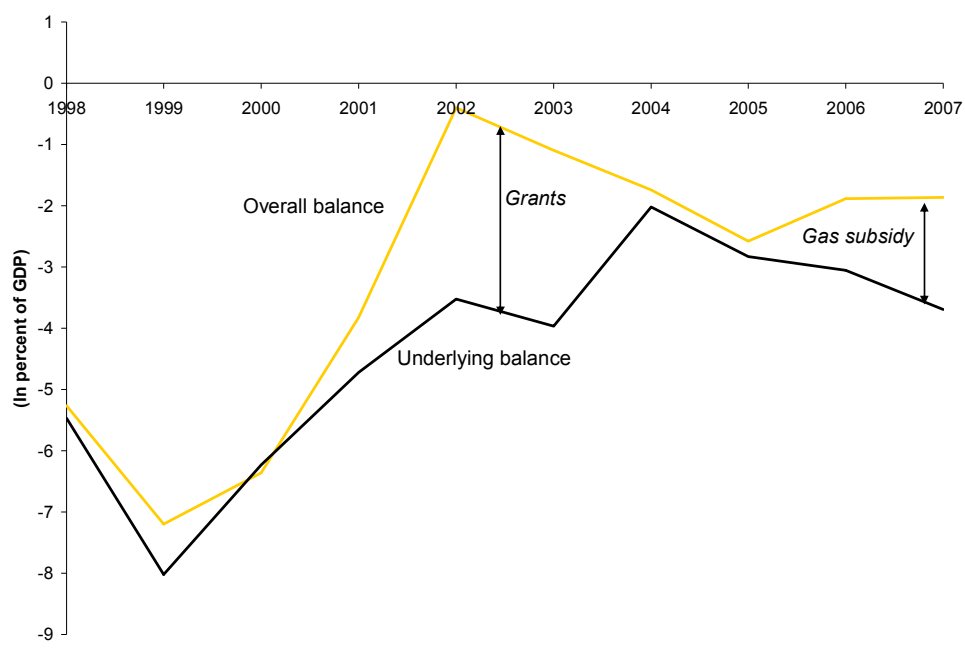

\section{Determining the impact of fiscal policy: the 'fiscal impulse'}

9. This section analyzes the effect of government spending on the Armenian economy. ${ }^{3}$ Instead of relying on the cyclically-adjusted underlying balance as a measure of fiscal policy

\footnotetext{
${ }^{3}$ For additional detail, see Gracia (2008).
} 
stance, we use a VAR framework to estimate the impact of changes in government spending on economic activity for the period 1998:1-2007:4. Net taxes are defined as the sum of tax revenues and nontax revenues, less transfer payments and net interest paid by the government, whereas government spending is defined as purchases of goods and services (current and capital). All macro-fiscal variables are transformed in real per capita terms.

10. The structural transformation of the Armenian economy since independence makes the identification of fiscal policy shocks challenging. Frequent changes in tax policy and an inadequate tax administration, combined with low compliance and a large informal economy make the relationship between tax revenues and economic activity weak and somewhat unpredictable. Against this background, we focus here on spending shocks, leaving tax shocks unidentified, in order to reduce the number of identifying assumptions. Government spending variables are taken as predetermined with respect to macroeconomic shocks and unanticipated changes in taxes. The underlying identification assumption is that changes in government spending are undertaken for reasons other than immediate reaction to macroeconomic conditions. The frequency of the data (quarterly) makes this assumption plausible.

\section{Impact of spending shocks}

11. Spending shocks appear to be expansionary and inflationary. Figure I.2 shows the impulse responses of the endogenous variables $\left(G_{t}, G D P_{t}, \operatorname{Inf}_{t}, \operatorname{Tax}_{t}\right)$ to a one percent shock to real (per capita) government spending. ${ }^{4}$ They are reported for a horizon of two years with one-standard deviation error bands calculated with Monte Carlo integration methods with 1000 replications. The expansionary effect of the increased spending could finance at most half of it, resulting in a significant deficit. Interestingly, it takes two quarters for prices to react to government spending shocks (although the response is not statistically significant).

12. In order to analyze the effect of fiscal policy on other relevant macroeconomic variables, the vector of endogenous variables is augmented with the particular variable of interest. Thus, the vector of endogenous variables becomes $\left(G_{t}, G D P_{t}, \operatorname{Inf}_{t}, \operatorname{Tax}_{t}, X_{t}\right)$, where $\mathrm{X}$ is the variable of interest (unemployment, consumption, investment, etc).

\footnotetext{
${ }^{4}$ All figures show the impulse responses of the relevant variables to a one percent shock to real (per capita) government spending. Given the evidence of non-stationarity, the VAR is estimated in first differences with no linear trend. Two lags are used. Results are virtually unchanged if interest rates are added to the vector of endogenous variables.
} 
Figure I.2. Armenia: Government Spending Shock

Response of Gov. Exp. to a Gov. Exp. Shock

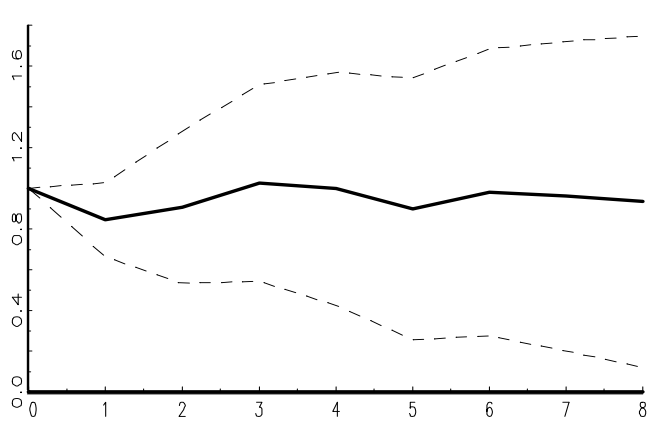

Response of Inflation to a Gov. Exp. Shock

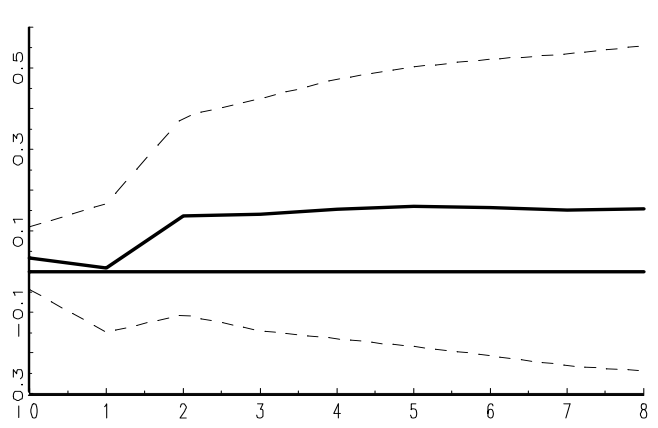

Response of GDP to a Gov. Exp. Shock

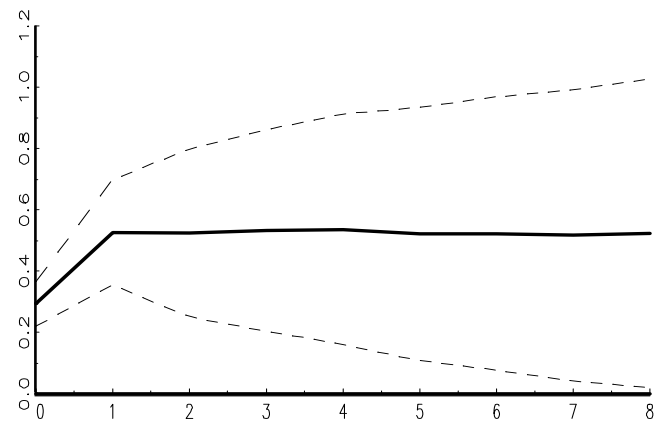

Response of Tax. Rev. to a Gov. Exp. Shock

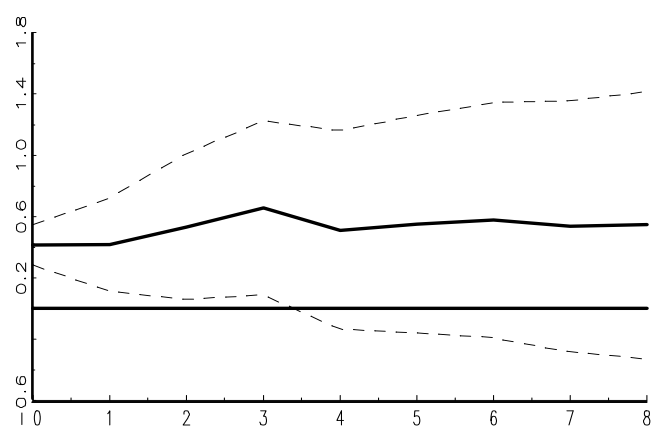

\section{Impact on labor market}

13. The responses of employment and the unemployment rate to a government spending shock have the expected signs (Figure I.3). The effect on employment is only statistically significant in the short-term, but the magnitude is small. The opposite, relatively large but insignificant response, applies to the unemployment rate. In both cases, the impact seems to be relatively persistent. These results should be interpreted with caution, given the high level of informality in Armenia and the systematic under-reporting of employment and wages.

Figure I.3. Armenia: Labor Market response to a Government Spending Shock

Response of Employment to a Gov. Exp. Shock

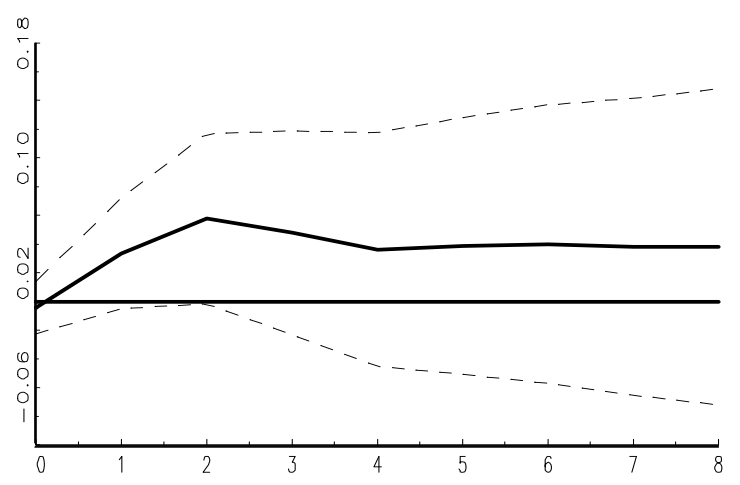

Response of Unemployment Rate to a Gov. Exp. Shock

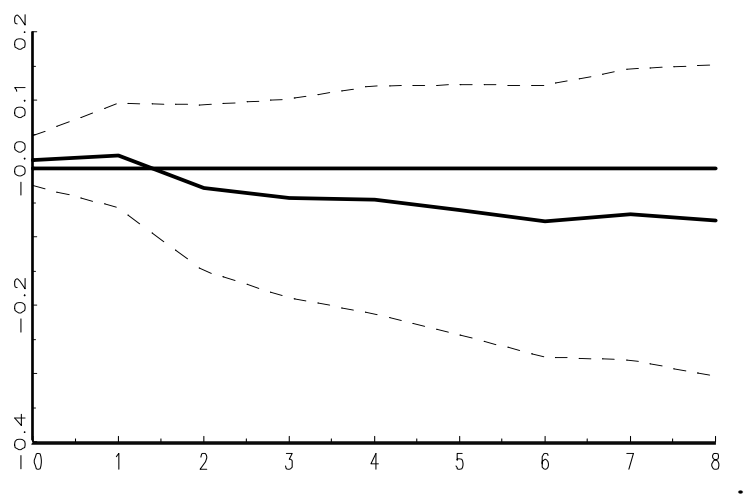




\section{Impact on economic activity}

14. Government spending has a positive effect on economic activity and GDP (Figure I.4). This is reflected in the relatively large and persistent impact on private per capita consumption (although it is not statistically significant after three quarters). Government spending seems to be complementary to private investment, which reacts strongly and positively to a positive spending shock. Manufacturing activity also responds positively to a government spending shock. Finally, government spending results in a widening of the trade deficit. This effect is large, persistent, and statistically significant for at least one year.

Figure I.4. Armenia: Response of Economic Activity to a Government Spending Shock

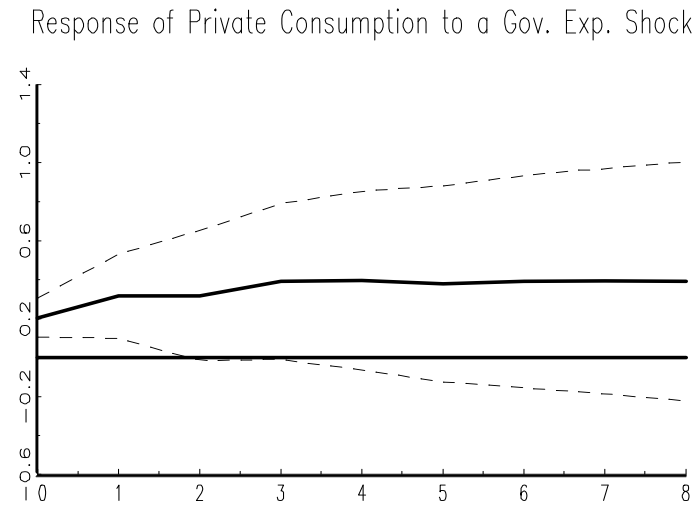

Response of Manufacture to a Gov. Exp. Shock

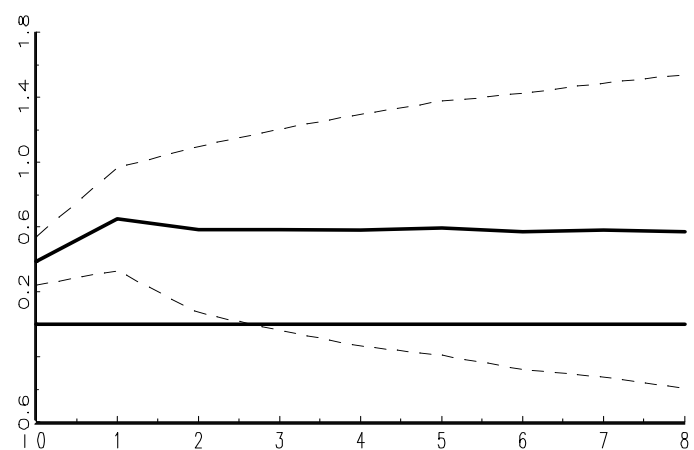

Response of Private Investment to a Gov. Exp. Shock
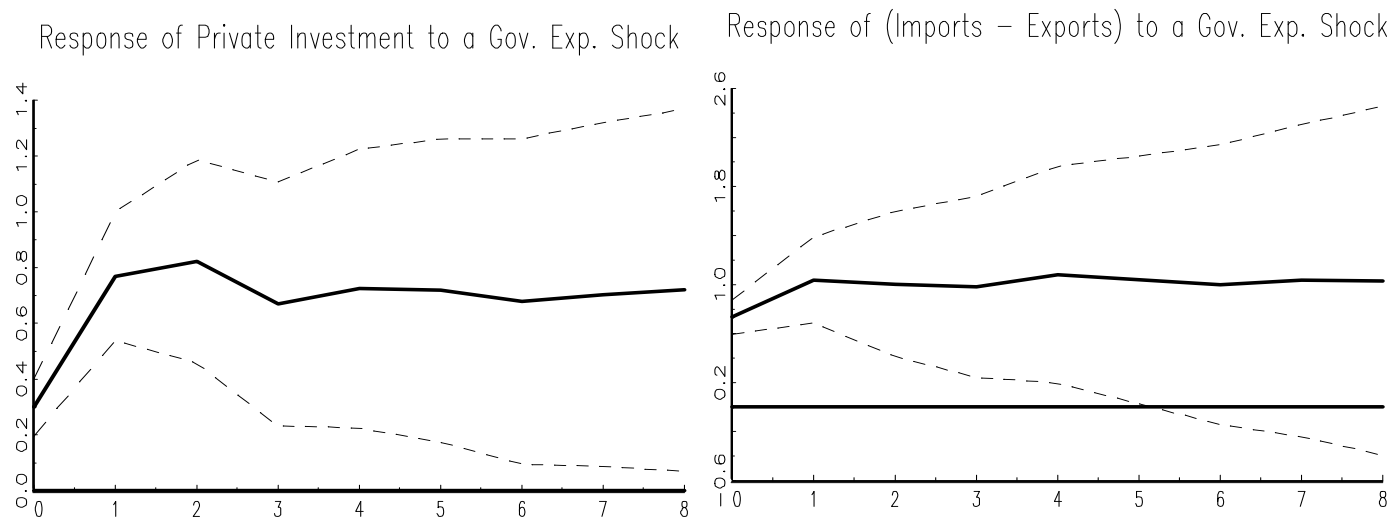

15. In sum, the evidence presented here suggests that there is scope for fiscal policy to be used as a short-term counter-cyclical tool in Armenia. The impact of fiscal spending on economic activity has the expected sign, and is statistically significant at least over the shortrun. Even though there is a lot of uncertainty involved in these estimations and the quality of the data places some questions on its exact interpretation, the estimates obtained suggest that a 1 percent increase in real per capita government spending can lead to up to 0.5 percent increase in per capita GDP. On the other hand, government spending exacerbates inflationary pressures, and results in larger fiscal deficits, as well as wider trade deficits. 


\section{Estimating a cyclically-adjusted fiscal balance}

16. The business cycle can, in principle, have large, temporary, effects on tax revenues and expenditures. Once a meaningful measure of the fiscal stance is established (as discussed in paragraphs 7-8), it is also important to separate cyclical factors from trends in the data to get a clearer understanding of the structural fiscal position. The cyclically-adjusted underlying fiscal balance provides such a measure of the fiscal stance by stripping away the component of both revenues and expenditures that can be attributed to business cycle fluctuations, identified as output deviations from its potential (the output gap).

\section{Estimating potential output and the output gap}

17. A Hodrick-Prescott (HP) filter is used here to estimate potential output. ${ }^{5}$ Figure I.5 shows the levels and growth rates of potential and real output, as well as the output gap using a value of $\lambda=100$ (generally used for annual data). ${ }^{6}$ The results suggest that in 1998 and 2003/04 the output gap was relatively small. Actual output remained below potential before 2003 (a negative output gap) but the growth rate of actual output has exceeded that of potential since 2001 (with the exception of 2004). As a result, actual output seems to have been above potential since 2005 .

Figure I.5. Armenia: Potential Output (Annual data)
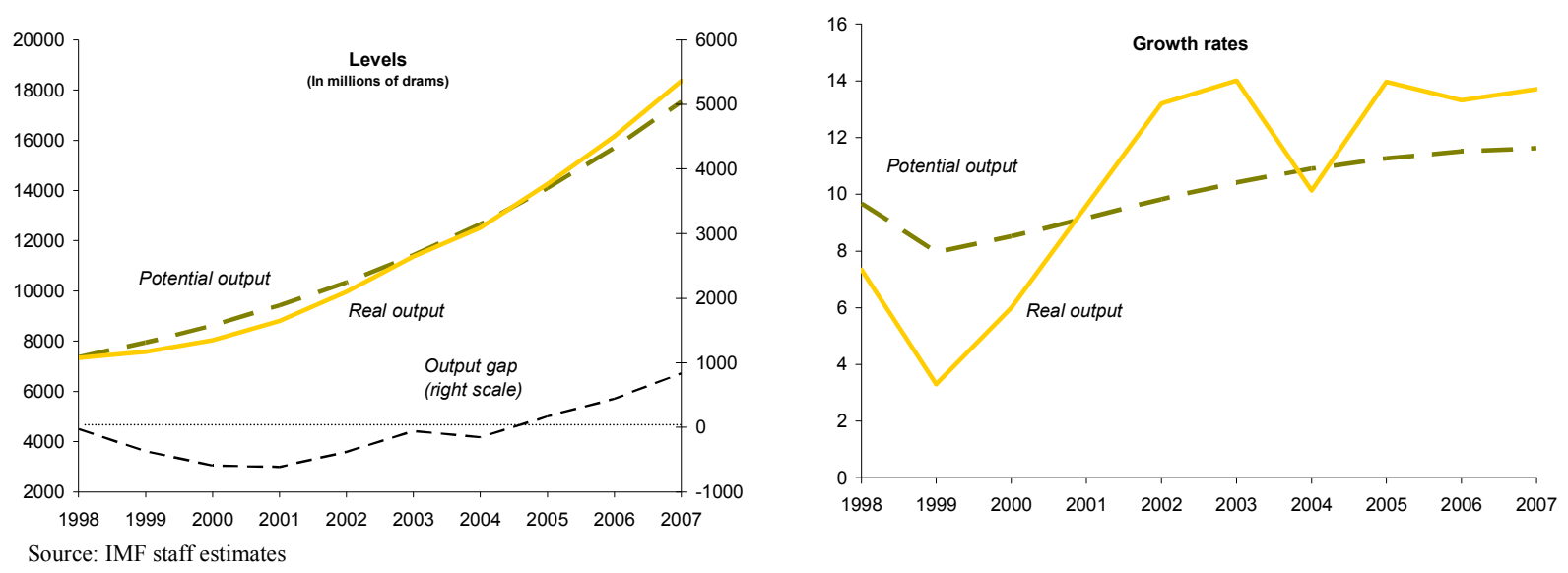

\footnotetext{
${ }^{5}$ An alternative approach, based on a production function relationship and the factor inputs in the economy, is not current applicable in the case of Armenia because of data limitations. For example, although national accounts provide a flow series for capital, there is no stock series available and, more importantly, as mentioned in paragraph 13 , labor inputs statistics are problematic.

${ }^{6}$ The HP filter was applied to the log of GDP. Annual data were used for the period 1994-2007, with the analysis focused on the period 1998-2007.
} 
18. Using (annualized) quarterly data, we obtain qualitatively similar results but smaller cycles. The difference at the beginning of the period (a positive output gap in 1998/99) is due to the different sample used (since 1994 for the annual data and 1996 for the quarterly data). As before, there is a negative output gap until 2005, after which there is an increasingly positive output gap (Figure I.6).

Figure I.6. Armenia: Potential Output (Annualized quarterly data)
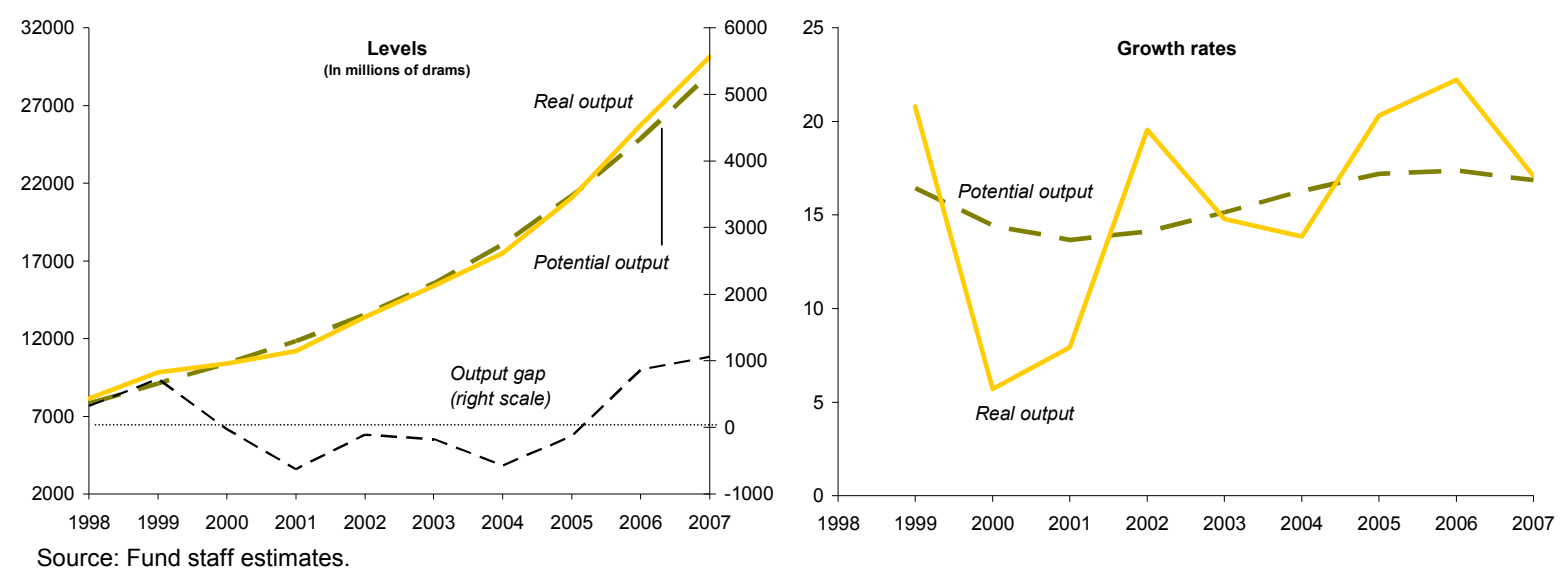

\section{Calculating the cyclically-adjusted fiscal balance}

19. The underlying assumption adopted here is that each component of the budget is adjusted proportionally to the ratio of potential to actual output, as determined by its output elasticity (see Giorno et. al. (1995)). That is,

$\frac{T_{i}^{P}}{T_{i}}=\left(\frac{Y^{p}}{Y}\right)^{\eta_{i}}, \frac{G^{p}}{G}=\left(\frac{Y^{p}}{Y}\right)^{\xi}$

Where $T$ is actual tax revenue (which could potentially be disaggregated by taxes, $i$ ), $G$ is actual current government expenditures, $\eta_{i}$ is the output elasticity of tax $i$ and $\xi$ is the output elasticity of current government expenditure (including the gas subsidy). Thus, the cyclically adjusted balance becomes,

$B^{p}=\sum_{i=1}^{n} T_{i}\left(\frac{Y^{p}}{Y}\right)^{\eta_{i}}-G\left(\frac{Y^{p}}{Y}\right)^{\xi}-G_{\text {capital }} \quad$ with $\eta_{i}>0, \xi<0$

where $G_{\text {capital }}$ is government spending on capital projects. 


\section{Tax revenues}

20. A simple approach to calculate the output elasticity of tax revenues is to use the contemporaneous coefficient from a regression of quarterly changes in real tax receipts on the first lead and lags 0 to 4 of changes in real output. This estimate yields the average elasticity over the period (rather than the actual for every quarter) and combines changes in tax policy and administration with automatic effects due to the business cycle. Given the uncertainty over the point estimate so obtained (0.47), the results presented here will focus on a range of feasible values for this elasticity, taking the minimum possible value (zero), and the maximum obtained for other countries (around 2). ${ }^{7}$

21. The negative gap in revenue when actual GDP was below potential could reach 2.5 percentage points of GDP if the elasticity is close to 2 . On the other hand, the cyclical, temporary, component of revenues in 2007 could be as large as 1.5 percentage points of GDP. Note that cyclical factors contributed marginally to revenue performance in 2003/04 (Figure I.7).

Figure I.7. Armenia: Cyclical Adjustment to Tax Revenues

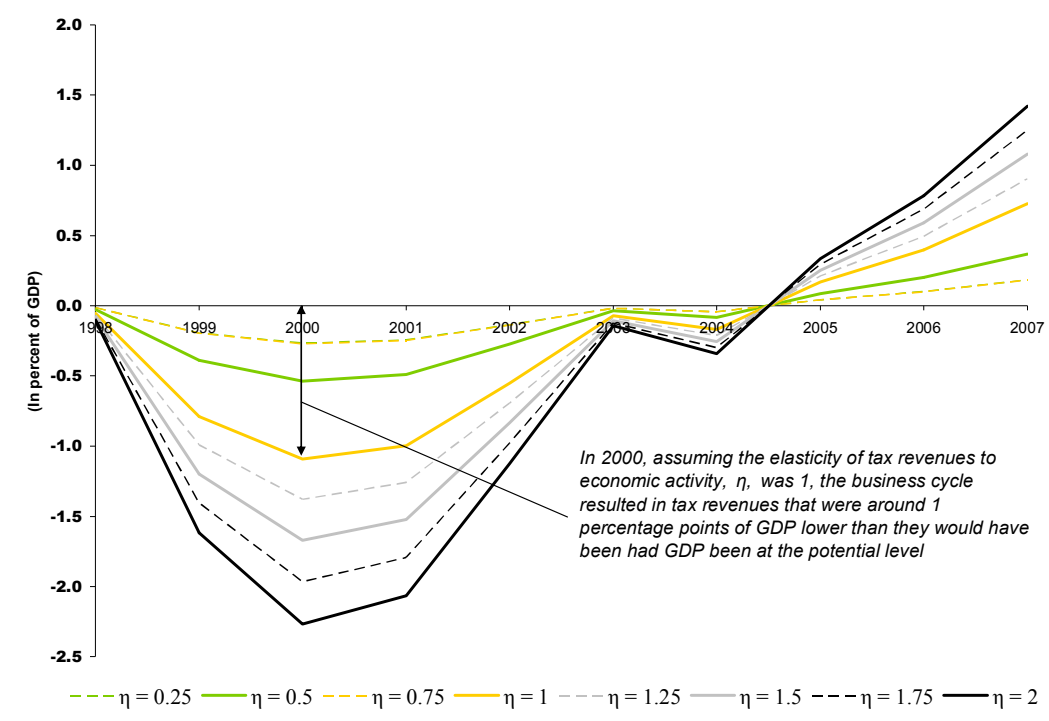

\section{Government spending}

22. Armenia has very weak automatic stabilizers. On the expenditure side, there are weak unemployment benefits or other countercyclical policies. On the revenue side, any nominal progressivity of the tax system is eliminated de facto by the tax administration practices

\footnotetext{
${ }^{7}$ The elasticity cannot be negative. As other studies have shown, it can range from $0.1,0.8$ and 0.9 for Australia, Great Britain and Germany, to around 1.9 for Canada and the U.S., as obtained by Perotti (2002).
} 
weakening the link between economic activity and tax collections. This would suggest that the output elasticity of current government spending should be close to zero. Thus, the elasticity estimate obtained by a regression equivalent to the one described above (-0.49), appears unrealistically high given the existing automatic stabilizers. Thus, a much smaller value, -0.1 , will be taken as a baseline. As before, the effect of the business cycle on current government spending over a range of elasticity values, $(-0.1,-0.8)$ is considered here. The effect on spending could be significant if the elasticity is relatively large, but in the absence of strong automatic stabilizers the cyclically-adjusted expenditure should not deviate much from actual expenditure (Figure I.8).

Figure I.8. Armenia: Cyclical Adjustment to Government Spending

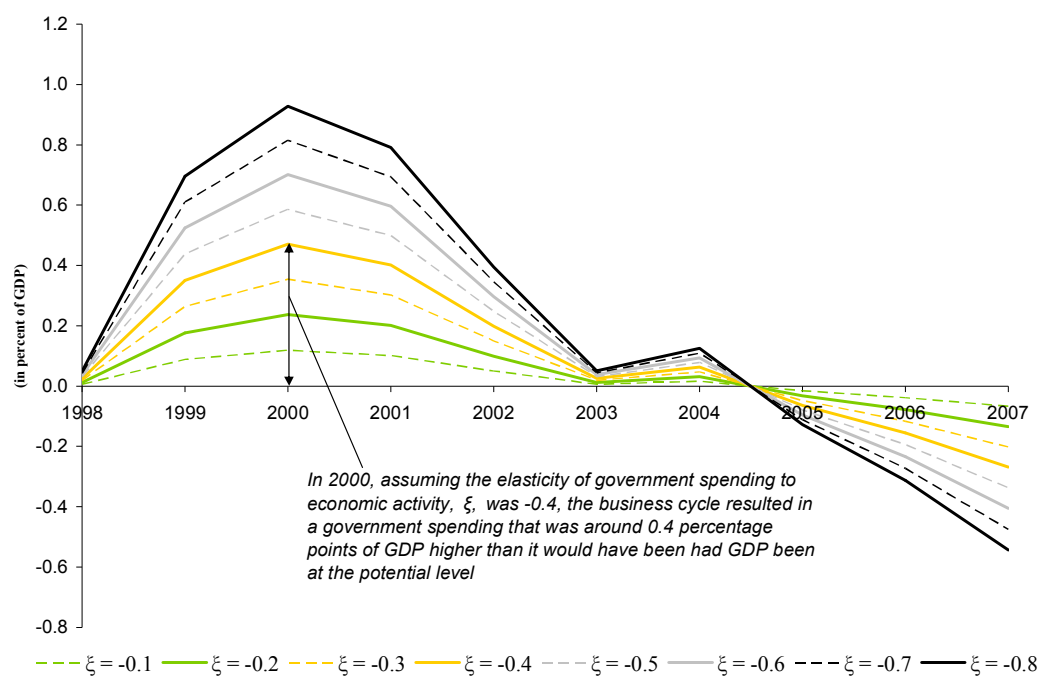

\section{Cyclically-adjusted balance}

23. Taking as baseline the elasticity obtained by the simple regressions $(0.47)$ for the tax elasticity, and a low, more realistic, elasticity for spending (-0.1), the cyclically-adjusted underlying balance for Armenia over the period 1998-2007 is shown in Figure I.9. The underlying balance defined in paragraph 7 is used as a measure of the fiscal stance. The difference between the cyclically-adjusted balance and the underlying balance (the gap) is also presented in the figure. 
Figure I.9. Armenia: Cyclically Adjusted Underlying Fiscal Balance

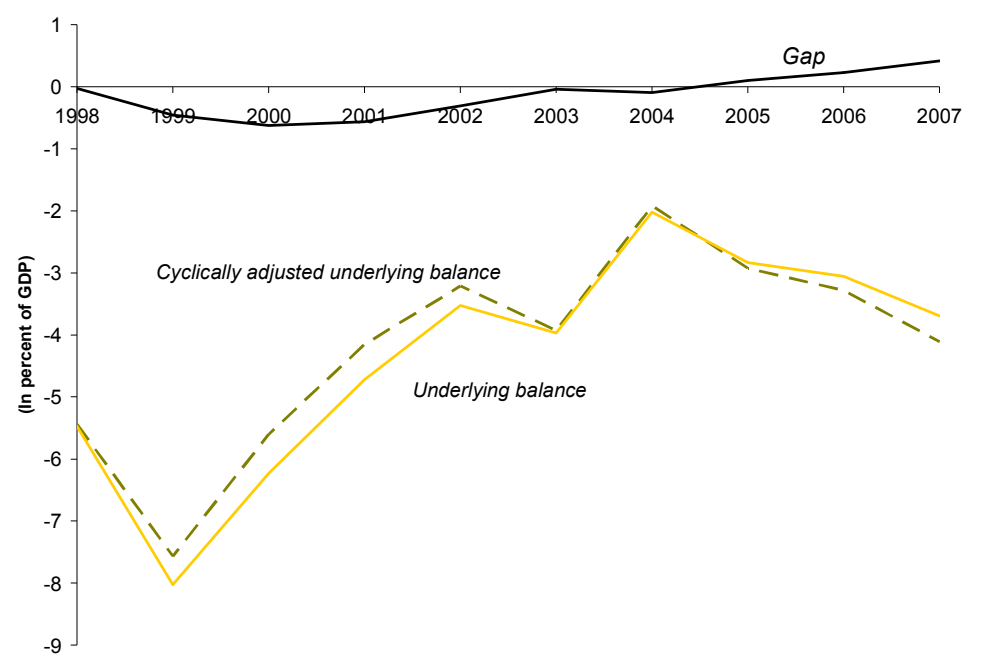

24. As shown by the gap, cyclical factors exacerbated the overall fiscal deficit during 1999-2004. This was also the time of an adjustment in fiscal policy that led to a cyclicallyadjusted deficit close to 2 percent of GDP in 2004. Since then, the cyclically-adjusted balance deteriorated at a faster rate than the overall balance at a time when actual output was growing above potential. In fact, by 2006 and 2007, cyclical factors helped reduce the size of the underlying deficit. This result holds, qualitatively, if quarterly data are used.

25. The assumption on elasticities determines the size of the gap between the underlying and potential balances. Figure I.10 presents different gaps for relatively low, more realistic, elasticity of government spending $(-0.1$ and -0.2$)$ and a low and medium tax revenue elasticity ( 0.25 and 1$)$. It also shows the baseline values. Not surprisingly, given the assumed low variability of government spending to the business cycle, the magnitude of the gap is mostly determined by the variability of revenues over the business cycle.

Figure I.10. Armenia: Cyclical Adjustment to Underlying Fiscal Balance

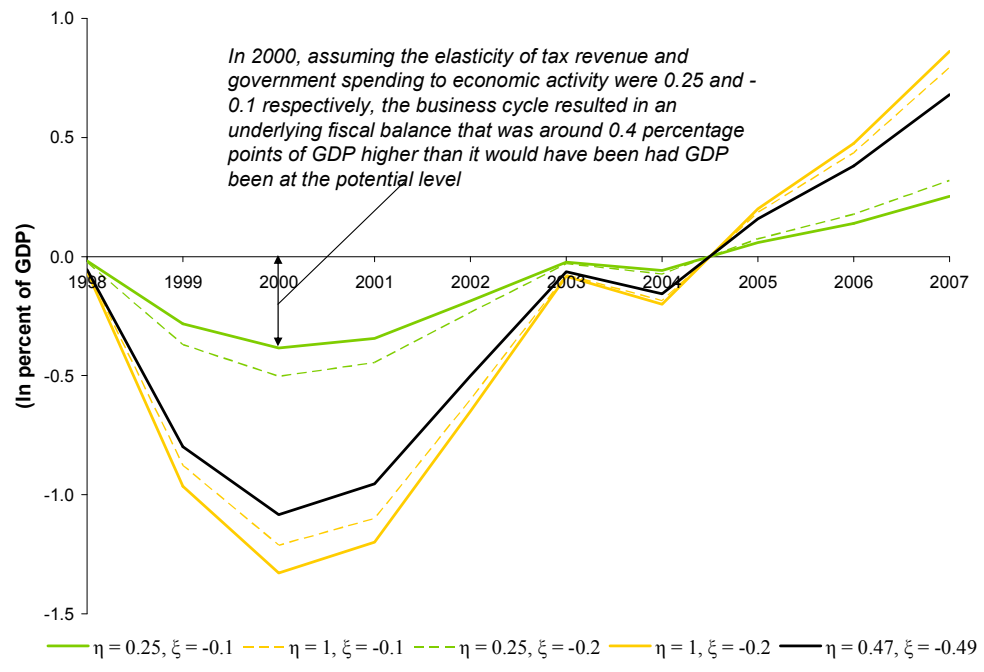


26. The key conclusion is that fiscal policy has been pro-cyclical over the last few years. Both the underlying and cyclically-adjusted balance show a deterioration of the fiscal position since 2004 - at a time when actual output was growing above potential. This conclusion cannot be reached by looking only at the overall balance according to budget definitions. Figure I.11 shows all three measures of the fiscal balance during 1998-2007. It is clear from the picture that once large grants inflows moderated after 2003 and 2004, the three concepts provide a similar diagnostic of the fiscal stance. The overall balance as a measure of the fiscal stance became distorted again with the introduction of the off-budget gas subsidy in 2006 . While, at first glance, the fiscal position seemed to have marginally improved, in reality it was steadily deteriorating.

Figure I.11. Armenia: Fiscal Stance Revisited

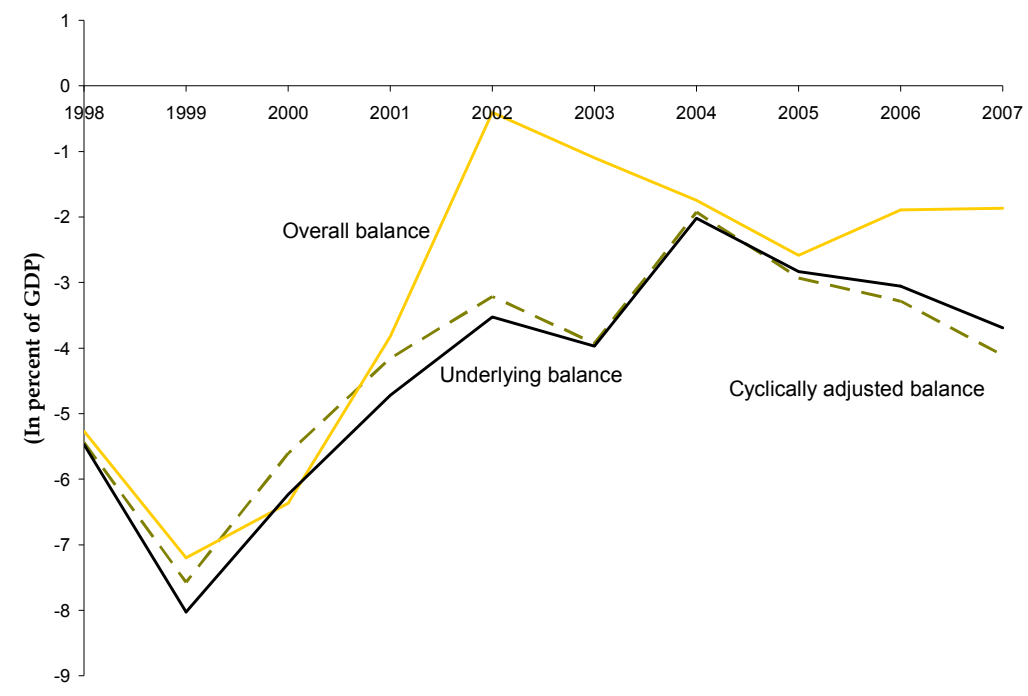

\section{Macro-fiscal unit}

27. The Armenian authorities are taking steps to establish a strategic, coordinated, and multi-year approach to macro-fiscal policy. Recent measures include strengthening public financial management systems, further institutionalizing the MTEF, and adopting performance-based budgeting over the next few years. In the last few months, macroeconomic projections and analysis have been strengthened with the use of fiscal impulse indicators for macro-fiscal analysis during the budget preparation. However, macrofiscal policy-making could benefit from a more elaborated analytical approach within an enhanced and supportive institutional environment.

28. Many countries have relied on strong macro-fiscal policy departments to strengthen their policy framework. Best international practice suggests that an effective macro-fiscal policy department should "own" its country's fiscal framework by helping: 
- $\quad$ Develop the fiscal framework, through forecasting, analysis, and monitoring of other short- and medium-term fiscal policy developments;

- Monitor the implementation of the fiscal framework, by assessing budget execution and by linking it to developments in other macroeconomic areas such as growth and inflation; and

- $\quad$ Protect the fiscal framework, by advising the Minister on emerging near and mediumterm risks; flagging the need to undertake corrective actions; and identifying possible alternatives.

29. The core tasks of the department should be well coordinated and carried out in close cooperation with other units within the Ministry of Finance, and relevant institutions with related responsibilities. The value added of the department would come from adopting a topdown or big-picture perspective, thus helping the work of other units in related areas:

By performing macroeconomic analysis the department should ensure an internallyconsistent macroeconomic framework.

$>$ By performing fiscal modeling, forecasting and impact analysis, the department should develop multi-year fiscal projections under the baseline of unchanged policies that allows to superimpose the impact of any expected or potential policy change, all of which could be included in budget documents. This task requires sound fiscal forecasting to examine the linkages from the real, monetary, and external sectors into the fiscal sector.

$>$ By aligning all aspects of fiscal policy toward the achievement of the government's economic objectives, the department should help create a consistent framework in which policies and objectives are clearly linked. The appropriate path for the fiscal aggregates within a specific time horizon can be chosen to attain objectives such as macroeconomic stability, medium-term growth, poverty reduction, and fiscal and debt sustainability. The impact of these targets on macroeconomic stability can be examined through macroeconomic analysis, while the appropriateness of the fiscal path's financing implications can be assessed through debt and fiscal sustainability analysis. Once a consistent set of policies is determined, revenue, expenditures and debt targets can be refined. A macro-fiscal policy department plays a key role in assessing this consistency, and also in identifying fiscal risks associated with the proposed policies, through the examination of alternative scenarios and stress tests.

$>$ By monitoring fiscal performance, the department should analyze in-year budget outcomes - financing, revenues, and expenditures; help explain deviations of outturns from plans; assess the implications of such deviations for end-year forecasts; and determine whether some in-year corrective measures are required. It should also participate in the design of such corrective policies from the analysis of their impact on 
the short- and medium-term. Close coordination with other departments is required to avoid duplication.

\section{Conclusion}

30. Expansionary fiscal policy seems to have a positive impact on economic activity and employment, although it also increases inflationary pressures and worsens the trade balance and the fiscal position of the central government. As a result, sustained expansionary fiscal policy may lead to increased macroeconomic imbalances, and threaten fiscal sustainability. Therefore, building up fiscal space during expansions is key for the effective implementation of stimulatory policies during downturns.

31. After an initial phase of fiscal consolidation until 2004, the underlying fiscal balance has steadily deteriorated at a time of rapid economic growth. Going forward, the fiscal stance should become more neutral. In the short run, if signs of overheating persist, the fiscal stance needs to be tightened to allow fiscal policy to play a more active stabilization role. On the other hand, if the international economic downturn impacts the Armenian economy significantly, a tighter fiscal stance may not be desirable. 


\section{REFERENCES}

Blanchard, Olivier, and Roberto Perotti, 1999, "An Empirical Characterization of the Dynamic Effects of Changes in Government Spending and Taxes on Output," Quarterly Journal of Economics.

Fatás, Antonio, and Ilian Mihov, 2001, "The Effects of Fiscal Policy on Consumption and Employment: Theory and Evidence," mimeo, INSEAD.

Giorno, Claude, Peter Richardson, Deborah Roseveare, and Paul van den Noord, 1995, "Estimating Potential Output, Output Gaps, and Structural Budget Balances," OECD Economics Department Working Paper, Vol. 152.

Gracia, Borja, 2008, Fiscal Policy in Armenia, mimeo (Washington: International Monetary Fund).

Perotti, Roberto, 2002, "Estimating the Effects of Fiscal Policy in OECD Countries," ENEPRI Working Paper, Vol. 15. 


\section{SMoothing EXchange RATE OR FUELling Inflation: WHAT ARE THE EFFECTS OF FOREIGN EXCHANGE MARKET INTERVENTION IN ARMENIA? ${ }^{1}$}

\section{A. Introduction}

1. During the past six years, the Armenian dram experienced a prolonged phase of considerable appreciation. Upward pressure on the exchange rate was brought about mainly by large foreign exchange inflows (first of all remittances, but also official donor assistance and increasingly foreign direct investment). It was reinforced by significant dedollarization, triggered by increasing confidence in the domestic currency and appreciation expectations. Between March 2003 and November 2007, the nearly doubled in value vis-à-vis the U.S. dollar, partly offsetting the previous depreciation experienced during the tumultuous early years of economic transition. Dram appreciation has contributed to low inflation and financial deepening, as households grew confident of the domestic macroeconomic and financial stability and began to reduce their cash dollar holdings.

2. At the same time, the speed and extent of dram appreciation has raised concerns about external competitiveness, leading to calls to limit the strengthening of the domestic currency. The Central Bank of Armenia (CBA) has remained committed to maintaining a flexible exchange rate regime, but has increasingly engaged in foreign exchange market interventions (Figure II.1) aimed at "moderating the rate of change and preventing undue fluctuations in the exchange rate, rather than establishing a level of it" (CBA exchange rate policy statement 2006 (Country Report No. 06/433, p.10). Acknowledging their more active role in the foreign exchange market, the authorities agreed with Fund staff to a reclassification of the exchange rate regime from "independently floating" to a "managed float with no predetermined path or level for the exchange rate" on the occasion of the 2006 Article IV consultations with the IMF in September 2006.

3. With inflationary pressures from surging food and energy import prices and buoyant domestic demand mounting, however, the consistency of foreign exchange market interventions with the CBA's inflation targeting strategy has been called into question. Foreign exchange purchases by the central bank have remained largely unsterilized, resulting in large injections of domestic currency liquidity into the market. Foreign exchange rate intervention has become the main driver of strong reserve money growth at a time when the monetary authorities have embarked on a path of monetary tightening through gradual but steady increases in the policy interest rate. This has fuelled an impressive surge in domestic credit growth over the past year, has potentially blunted the interest rate channel of monetary policy, and - given the long-term positive relationship between money and prices-is likely to contribute to higher inflation in the period ahead.

\footnotetext{
${ }^{1}$ Prepared by Holger Floerkemeier.
} 
Figure II.1. Armenia: Exchange Rate and Foreign Exchange Market Intervention
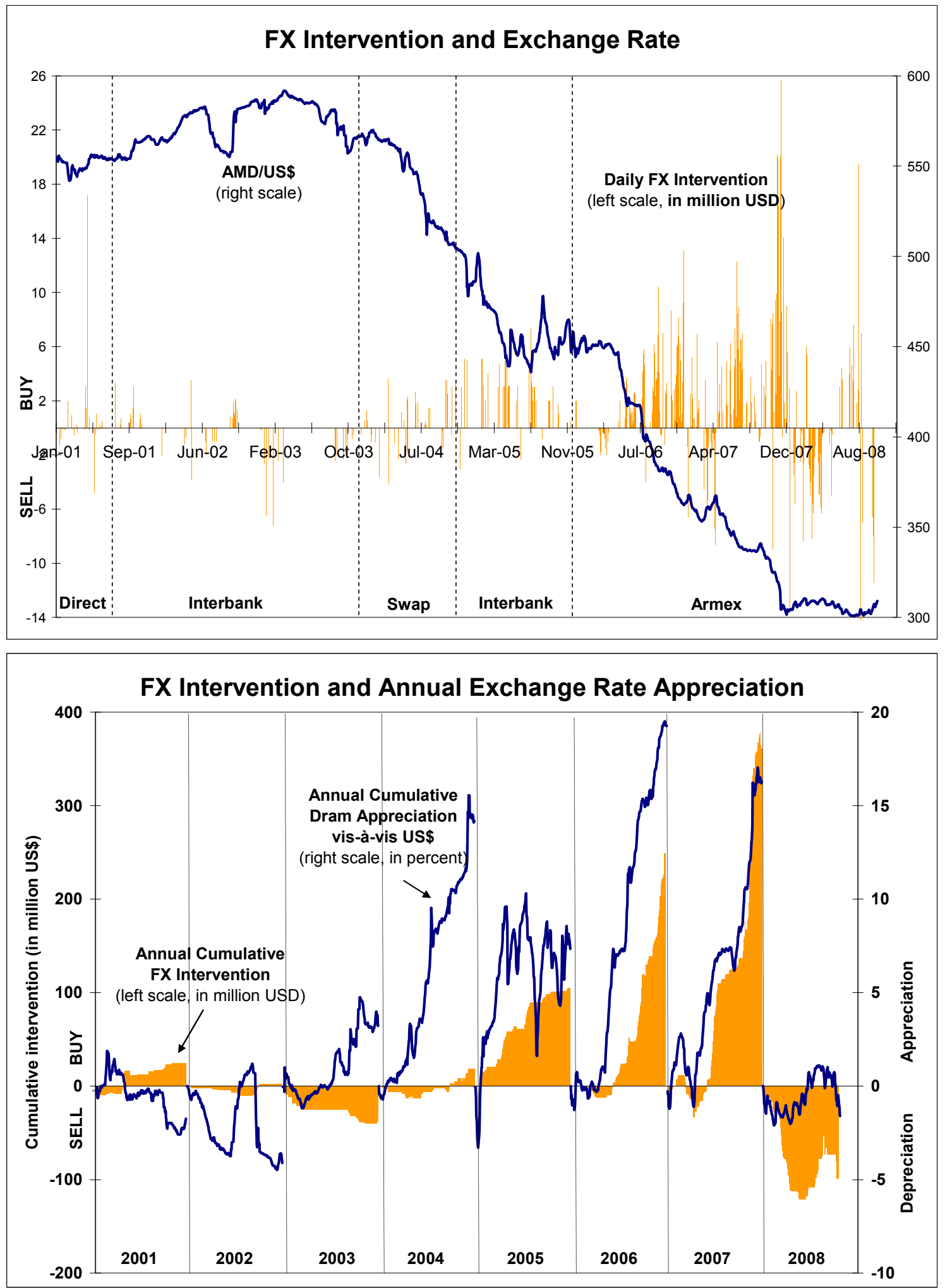

Source: Central Bank of Armenia. 
4. This paper investigates the effectiveness of CBA foreign exchange market intervention during the period January 2001 to May 2008, focusing on the recent period of strong dram appreciation pressures. Policy effectiveness is measured in terms of the impact of interventions on the level and volatility of exchange rate returns (daily percentage changes in the exchange rate). To this end, the paper employs GARCH (Generalized Autoregressive Conditional Heteroskedasticity) model specifications over various subperiods.

5. The empirical findings presented in section $\mathrm{C}$ point to the limited effectiveness of foreign exchange market interventions. Intervention does not seem to have had a substantial impact on dram exchange rate returns. While this is in line with the CBA's official exchange rate policy objectives (and could be interpreted as consistent with a cautious "leaning against the wind" strategy), the GARCH models also lend only tentative support to the claim that interventions have contributed to reducing the volatility of the exchange rate.

6. However, these results should be interpreted with caution. Intervention data are only available with a daily frequency, and it may well be that interventions have been effective in moderating intraday exchange rate volatility in a thin foreign exchange market, exposed to large swings in trade volumes and lumpy foreign exchange flows.

7. The results are largely consistent with studies investigating the experience with foreign exchange market intervention in other countries. While generally no long-term effects of intervention on the level of the exchange rate can be found, the economic literature lends tentative support to significant, albeit small, short-term effects of foreign exchange market intervention in advanced economies. ${ }^{2}$ Evidence for the effectiveness of intervention in developing and transition countries is rather mixed, and interventions are occasionally found to increase exchange rate volatility. ${ }^{3}$ In theory, several factors would suggest that foreign exchange interventions may be more effective in developing and transition countries than in advanced economies (Canales-Kriljenko, 2003): central banks often do not fully sterilize interventions so that interventions can impact the exchange rate via the monetary policy channel; foreign exchange market regulations often increase central banks' information advantage; and the size of interventions is usually high relative to the foreign exchange market turnover.

\footnotetext{
${ }^{2}$ See, for example, Dominguez and Frankel (1993), Ito (2002), and Dominguez (2003) for evidence in industrial countries, or Edison (1993) and Sarno and Taylor (2001) for surveys of the literature.

${ }^{3}$ While some studies find significant effects of intervention on the exchange rate level, such as Akinzi et al. (2005a,b) and Herrera and Özbay (2005) for Turkey, Tapia and Tokman (2004) for Chile, and Kamil (2008) for Colombia, others find no convincing evidence, see for example Domac and Mendoza (2002) and Guimaraes and Karacadag (2004) for Turkey and Mexico, or Disyatat and Galati (2005) and Égert and Komárek (2006) for the Czech Republic.
} 


\section{B. Foreign Exchange Market Trends and Intervention Policies}

8. The Armenian foreign exchange market is characterized by a small number of market participants and comparatively low, but volatile turnover. It exhibits large exposure to lumpy foreign exchange flows from external trade transactions, foreign direct investments (in particular bank capital inflows, since 2007), and loan or grant disbursements. The retail market - including external trade and investment operations as well as money transfers-is dominated by commercial banks, while a large number of foreign exchange bureaus that are confined to business with households make up only a very small share of the market. Transactions take place in the spot market, and only a small number of banks have recently started to offer foreign exchange forward products. The wholesale market is relatively small compared to the retail market, with an average share of approximately 20 percent of total turnover, subject to significant variations ranging between 0 and 50 percent (Figure II.2).

9. The CBA maintains a flexible exchange rate regime, but reserves the right to intervene in the foreign exchange market to secure orderly market conditions and reduce exchange rate volatility. The CBA conducts interventions primarily in the onshore wholesale spot market, during normal business hours and without prior announcement. Intervention data are published by the CBA on a weekly basis.

10. Foreign exchange market intervention has remained largely unsterilized. Apart from issuing its own short-term securities, the CBA has not had the instruments to sterilize liquidity injections or withdrawals resulting from intervention. Net issuance of CBA securities for liquidity management purposes amounted to around AMD28 billion in 2006 and AMD10 billion in 2007, compared to net liquidity injections from foreign exchange market intervention of AMD95 billion in 2006 and AMD117 billion in 2007, respectively.

11. The monetary policy channel is the main transmission path from intervention to the exchange rate in Armenia, because unsterilized intervention has a direct impact on reserve money. Even though interventions are not announced, they may also have a certain impact through the signaling channel, since the CBA market activity is easily observable by market participants. In the presence of volatile and lumpy foreign exchange flows, the microstructure (order flow) channel may be of special importance in Armenia, but it is impossible to empirically investigate the intraday impact of intervention in the absence of ultra-high frequency data.

12. There have been several changes in intervention operations since 2001: until June 2001, the CBA conducted direct conversions, transacting with both banks and large retail market participants. Between June 2001 and October 2003, interventions were conducted on the OTC interbank spot market. From October 2003 to October 2004, the CBA used currency swaps, before shifting back to interbank market spot purchases and sales until November 
2005. Since then, the OTC interbank market has been largely replaced by transactions on the electronic trading platform of ARMEX, the local stock exchange (Figure II.1).

Figure II.2. Armenia: Foreign Exchange Market Characteristics
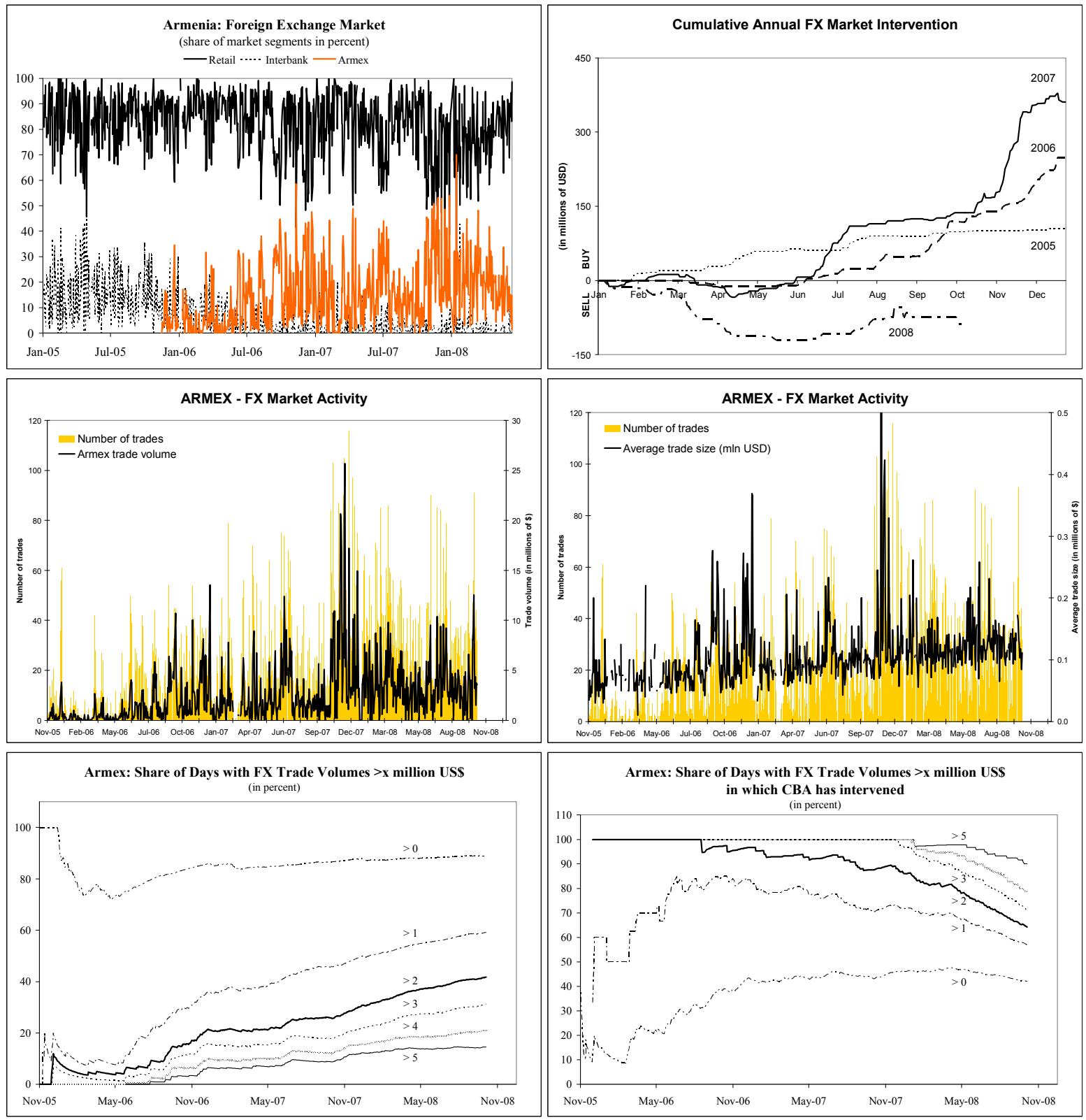

Sources: Central Bank of Armenia and ARMEX, author's calculations.

13. Foreign exchange trade volumes on ARMEX are relatively low on average, but exhibit very high volatility (Figure II.2). Trading activity has increased significantly since June 2006-about six months after trading started at ARMEX. But average daily trade volumes are still low (around \$3.2 million in 2007/08), not exceeding \$1 million on almost half of trading days, and exceeding $\$ 5$ million on only about 15 percent of trading days. On active trading days, there are between 20-25 trades with an average contract size of close to 
$\$ 100,000$, but both trading activity and size of individual trades are substantially higher in some subperiods.

14. Exchange rate developments since 2003 have been characterized by large foreign exchange inflows (remittances, donor assistance, foreign direct investment). These inflows have resulted in strong and persistent appreciation pressures, compounded by significant financial and cash dedollarization (Figure II.3). While deposit and credit dollarization have closely followed exchange rate trends since 2005 , data availability on cash dollarization are very limited. Several household surveys conducted by the CBA suggest that cash dollar holdings in Armenia are still significant, exceeding M2X (broad money including foreign currency deposits) by a wide margin. Assuming that cash dollar holdings have been reduced in tandem with financial dedollarization, cash dedollarization must have been substantial, adding significantly to the appreciation pressures observed during the past years.

Figure II.3. Armenia: Financial Dedollarization and Cash Dollar Holdings

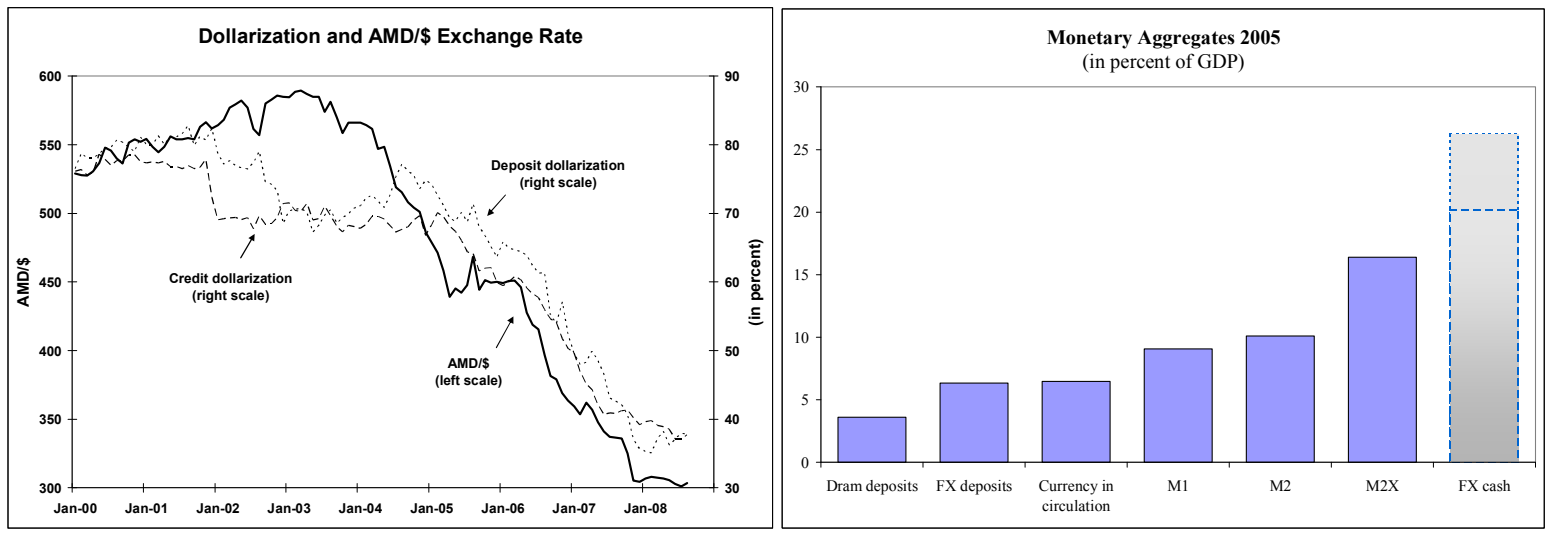

Source: Central Bank of Armenia.

15. Foreign exchange inflows and interventions follow a seasonal pattern. Economic activity, exports, and remittance inflows are usually lower during the first quarter, resulting in relative subdued foreign exchange market turnover and intervention activity. During this period, CBA interventions involve mainly foreign exchange sales for liquidity management. ${ }^{4}$ Remittances, capital inflows, and resulting appreciation pressures are normally strongest during the fourth quarter. Consequently, CBA foreign exchange purchases have taken place mainly during the last three to four months of the year.

16. Reflecting both persistent appreciation pressures and heightened volatility in the foreign exchange market, CBA foreign exchange market interventions increased substantially

\footnotetext{
${ }^{4}$ In early 2008, the CBA also conducted foreign exchange sales to stabilize the exchange rate in an environment of heightened political uncertainty.
} 
between 2005 and 2007. From 2001 to 2003, CBA net foreign exchange sales amounted to between 15 and 20 percent of beginning-of-year reserve money. With dram appreciation commencing in 2003, foreign exchange market interventions resulted in net purchases since 2004 and increased significantly until 2007, when they exceeded 90 percent of end-2006 reserve money. With appreciation pressures diminished in 2008 by surging import demand, a rebalancing of private-sector dollar holdings in reaction to excessive appreciation expectations in late 2007, and heightened political and regional uncertainty, CBA intervention activity has moderated, once again turning back to net foreign exchange sales.

\section{Econometric Investigation}

\section{Data}

17. Data on daily dram/dollar spot exchange rates, foreign exchange market interventions, and interbank interest rates were obtained from the CBA. Euro/dollar exchange rates, overnight and two-week LIBOR rates, and daily oil price data were taken from Bloomberg. The data sample covers the period from January 3, 2001 to May 30, 2008. Table II.1 presents summary statistics of the variables used in the models.

Table II.1. Armenia: Summary Statistics

\begin{tabular}{|c|c|c|c|c|c|c|c|c|c|}
\hline & Mean & Median & Maximum & Minimum & Std. Dev. & Skewness & Kurtosis & Jarque-Bera & Stationarity \\
\hline $\mathrm{AMD} / \$$ exchange rate & 483.31 & 513.73 & 591.76 & 301.5 & 93.816 & -0.570 & 1.892 & 203.66 & no \\
\hline AMD daily exchange rate return $\left(\Delta\left(\operatorname{lns}_{\mathrm{t}}\right)\right.$ & 0.000 & 0.000 & 0.034 & -0.027 & 0.003 & 0.150 & 33.477 & $74,893.39$ & yes \\
\hline AMD deviation from $\mathrm{HP}$ trend $\left(\mathrm{HP} \Delta \mathrm{s}_{\mathrm{t}}\right)$ & 0.000 & 0.684 & 26.006 & -19.641 & 6.087 & -0.320 & 4.111 & 132.46 & yes \\
\hline Foreign exchange purchases $\left(\mathrm{I}_{t}{ }_{t}\right)$ (in million $\$$ ) & 0.493 & 0.000 & 25.690 & 0.000 & 1.806 & 6.269 & 57.595 & $252,984.30$ & \\
\hline Foreign exchange sales $\left(\mathrm{I}_{\mathrm{t}}^{\mathrm{S}}\right.$ ) (in million $\$$ ) & 0.182 & 0.000 & 13.425 & 0.000 & 0.884 & 7.077 & 65.230 & $328,372.50$ & \\
\hline Euro daily exchange rate return $\left(\Delta \operatorname{lne}_{t}\right)$ & 0.000 & 0.000 & 0.024 & -0.024 & 0.006 & 0.056 & 4.040 & 88.22 & yes \\
\hline 1st Diff. AMD/LIBOR interest differential $\left(\Delta\left(\mathrm{i}-\mathrm{r}^{\star}\right)_{\mathrm{t}}\right)$ & -0.010 & 0.001 & 6.720 & -6.440 & 0.968 & -0.111 & 12.442 & $7,191.76$ & yes \\
\hline 1st Diff. One-year-lagged MA oil price change $\left(\Delta(\mathrm{oil})_{t}\right)$ & 0.000 & 0.000 & 0.021 & -0.024 & 0.007 & -0.131 & 3.040 & 5.67 & yes \\
\hline
\end{tabular}

\section{Methodology}

18. The impact of CBA foreign exchange market intervention on the level and volatility of dram/dollar exchange rate returns is analyzed using the GARCH framework. ${ }^{5}$ A standard GARCH(1,1) serves as base model, and several model variants - including different explanatory variables and alternative GARCH specifications - were estimated to test for robustness of results.

19. Simultaneity is a potentially important problem when estimating the impact of intervention on the exchange rate (Neely 2005). This is because interventions themselves can

\footnotetext{
${ }^{5}$ See Bollerslev (1986) and Taylor (1986).
} 
be expected to be a function of past exchange rate changes, i.e. significant exchange rate movements may lead the central bank to intervene in the foreign exchange rate market to influence the exchange rate level and/or moderate the volatility of the exchange rate. According to Fratzscher (2005), simultaneity may result in a downward bias in the coefficient estimates, so that the effectiveness of intervention may be underestimated. Following Kamil (2008), this study employs a two-stage instrumental variable approach to overcome this identification problem. ${ }^{6}$ In the first step, the CBA policy reaction function is estimated using a TOBIT dynamic censored regression model. The predicted values from this model are then used as instruments in the GARCH specification.

20. In the first stage, the CBA's foreign exchange intervention policy reaction function is estimated separately for foreign exchange purchases $(x=p)$ and sales $(x=s)$, using the following TOBIT specification:

$$
I_{t}^{x}=\max \left(0, \gamma_{0}+\gamma_{1} I_{t-1}+\gamma_{2}\left(\Delta s_{t-1}\right)+\gamma_{3}\left(\ln s_{t-1}-\ln s_{t-1}^{T}\right)\right)+\varepsilon_{t}
$$

The dependent variable $I_{t}$ is the actual amount of dollar purchases (sales), $s_{t}$ is the nominal dram/dollar exchange rate, and $s^{T}$ is the 20 -day moving average exchange rate. ${ }^{7}$ Therefore, intervention is estimated as a function of one-day lagged intervention and exchange rate changes, as well as a percentage deviation of the exchange rate from its moving average as a measure of a short-term moving target rate, under the hypothesis that the CBA "leans against the wind" in order to avoid excessive short-term exchange rate swings.

21. The second stage estimates the impact of intervention on the size and volatility of exchange rate returns, employing a $\operatorname{GARCH}(1,1)$ model of the dram/dollar exchange rate:

$$
\begin{aligned}
\Delta\left(\ln s_{t}\right)= & \beta_{0}+\beta_{1} \Delta\left(\ln s_{t-1}\right)+\beta_{2} \overline{I_{t}^{P}}+\beta_{3} \overline{I_{t}^{s}}+\beta_{4} \Delta\left(\ln e_{t}\right)+\beta_{5} \Delta\left(i-r^{*}\right)_{t} \\
& +\beta_{6} \Delta\left(O I L_{t}\right)+\varepsilon_{t} \\
\varepsilon_{t} \mid \Omega_{t-1} \sim & N\left(0, \sigma_{t}^{2}\right)
\end{aligned}
$$

\footnotetext{
${ }^{6}$ For comparison, GARCH models were also estimated using the original intervention data. Both coefficient estimates and significance levels turned out to be fairly similar to the results reported in this paper.

${ }^{7}$ Alternative model specifications including LIBOR/dram interest rate differentials and/or different lag lengths of the exchange rate or the dependent variable were also tested.
} 


$$
\begin{aligned}
\sigma_{t}^{2}= & \alpha_{0}+\alpha_{1} \sigma_{t-1}^{2}+\alpha_{2} \varepsilon_{t-1}^{2}+\alpha_{3} \overline{I_{t}^{P}}+\alpha_{4} \overline{I_{t}^{s}}+\alpha_{5} \Delta\left(\ln e_{t}\right)+\alpha_{6} \Delta\left(i-r^{*}\right)_{t}+\alpha_{7} \Delta\left(\text { OIL }_{t}\right) \\
& +\sum_{i}^{4} \delta_{i} D_{i t}+\delta_{5} H_{t}+\delta_{6} P_{t}+v_{t}
\end{aligned}
$$

where $\Delta\left(\ln s_{t}\right)$ is the daily percentage nominal exchange rate return (a positive sign denoting a depreciation); $\overline{I_{t}^{P}}$ and $\overline{I_{t}^{S}}$ are the instrumented amounts of CBA exchange rate purchases and sales taken from the first stage; $\Delta\left(\ln e_{t}\right)$ is the daily Euro/dollar nominal exchange rate return to capture exogenous factors influencing relative dollar strength or weakness; $\Delta\left(i-r^{*}\right)_{t}$ is the first-differenced interest differential between the domestic interbank rate and LIBOR in percent per year; $\Delta\left(O I L_{t}\right)$ is the first differenced monthly moving average of oneyear lagged annual oil price changes as a rough proxy for foreign exchange inflows; ${ }^{8} D_{i j}$, $H_{t}$, and $P_{t}$ are day-of-the week, holiday, and post-holiday dummies. $\varepsilon_{t}$ represents the unexpected exchange rate return, and $\sigma_{t}^{2}$ corresponds to the conditional variance. The conditional distribution of the disturbance term is assumed normal with time-varying variance $\sigma_{t}^{2}$.

22. Equation (2) shows the mean equation of the model, estimating exchange rate returns as a function of intervention and a set of variables controlling for other factors that potentially have an impact on the exchange rate: relative dollar strength, changes in interest rate differentials, and changes in the growth of foreign exchange inflows (as proxied by the oil price variable). If exchange rate intervention is effective in influencing the level of the exchange rate, then foreign exchange purchases will depreciate the domestic currency $\left(\beta_{2}>0\right)$ and foreign exchange sales will appreciate the domestic currency $\left(\beta_{3}<0\right)$.

23. Equation (4) shows the variance equation, which contains GARCH and ARCH effects and the same set of explanatory variables plus a set of day-of-the-week and holiday dummies. If exchange rate intervention is effective in moderating exchange rate volatility, both intervention variable coefficients should be significant with a negative sign $\left(\alpha_{3}<0 ; \alpha_{4}<0\right)$.

\footnotetext{
${ }^{8}$ A large part of remittance inflows originates from Russia, These inflows are heavily dependent on economic developments in the Russian construction and services sectors, which have boomed in recent years following the surge in energy commodity prices (Atoyan and Oomes, 2006). More recently, an increasing share of buoyant foreign direct investment inflows has also been coming from Russia.

${ }^{9}$ The summary statistics in Table 1 suggest that neither dram/dollar exchange rate returns, nor most of the righthand side variables are normally distributed. Likewise, the residuals in the GARCH estimations appear not to be conditionally normally distributed, exhibiting fat tails. Bollerslev-Wooldridge robust standard errors and covariances are therefore used in the regressions. Alternative distributional assumptions (e.g. Student's t) were also employed to test for robustness, with broadly similar results for the main parameters under investigation.
} 
24. As an alternative to testing the impact of intervention on daily exchange rate changes, the above model was also estimated using daily deviations of the exchange rate from the long-term trend of the exchange rate, where the trend is modeled using an Hodrick-Prescott filter. ${ }^{10}$ This model acknowledges to a greater degree the flexible exchange rate regime adhered to by the CBA. That is, the exchange rate policy objective is not to target a specific level of the exchange rate but to moderate excessive daily exchange rate fluctuations around a market-determined exchange rate path.

\section{Results}

\section{Determinants of foreign exchange intervention}

25. First stage estimation results of the determinants of foreign exchange intervention are reported in Table 2. CBA foreign exchange purchases and sales are fairly well explained by exchange rate movements and intervention clustering. Both the coefficients of immediate exchange rate movements $\left(\Delta s_{t-1}\right)$ and of the deviation from a short-term moving average $\left(\left(\ln s_{t-1}-\ln s_{t-1}^{T}\right)\right)$ indicate that exchange rate appreciation (depreciation) triggers foreign exchange purchases (sales). This is consistent with a "leaning against the wind" intervention strategy followed by the CBA, with the aim to smooth the speed of exchange rate adjustments. In the case of foreign exchange purchases, only the coefficient for the deviations from the moving average is significant - perhaps not surprising considering the long phase of significant appreciation during the period of examination. The coefficients for lagged intervention suggest strong intervention clustering, i.e. an intervention on one day is likely to be followed by another intervention (in the same direction) on the following day. ${ }^{11}$

\footnotetext{
${ }^{10}$ The smoothing parameter $\lambda$ was chosen following the Ravan-Uhlig frequency rule with power 2 , based on 261 business days per year.

${ }^{11}$ In this modeling stage, foreign exchange purchases are defined as positive dollar values and foreign purchase sales as negative dollar values. In the following GARCH model specification, in which purchases and sales enter as separate regressors, both variables are defined as positive dollar values.
} 
Table II.2. Determinants of CBA Foreign Exchange Intervention

\begin{tabular}{|c|c|c|}
\hline & FX_P & FX_S \\
\hline C & $\begin{array}{l}-6.911^{* * *} \\
(0.424)\end{array}$ & $\begin{array}{l}-5.811^{* * *} \\
(0.442)\end{array}$ \\
\hline$I_{t-1}$ & $\begin{array}{l}1.07^{* * *} \\
(0.079)\end{array}$ & $\begin{array}{l}-1.00 \text { *** } \\
(0.121)\end{array}$ \\
\hline$\Delta s t-1$ & $\begin{array}{r}-19.44 \\
(74.433)\end{array}$ & $\begin{array}{l}185.58 \text { ** } \\
(77.901)\end{array}$ \\
\hline$\left(\ln s t-1-\ln s^{t} t-1\right)$ & $\begin{array}{l}-143.39 \\
(21.618)\end{array}$ & $\begin{array}{r}\mathbf{5 6 . 3 9} \\
(21.825)\end{array}$ \\
\hline SCALE:C(5) & $\begin{array}{l}\mathbf{5 . 1 4} \\
(0.249)\end{array}$ & $\begin{array}{l}4.21 \text { *** } \\
(0.269)\end{array}$ \\
\hline $\begin{array}{l}\text { Mean dep var } \\
\text { S.E. of reg } \\
\text { Prob > LR }\end{array}$ & $\begin{array}{l}0.494 \\
1.564 \\
0.000\end{array}$ & $\begin{array}{r}-0.182 \\
0.844 \\
0.000\end{array}$ \\
\hline Left cens obs & 1656 & 0 \\
\hline Right cens obs & 0 & 1761 \\
\hline Uncensored obs & 278 & 173 \\
\hline Total obs & 1934 & 1934 \\
\hline
\end{tabular}

Note: The estimated coefficients of the Tobit model do not have a direct interpretation as the marginal effect of the associated regressor $\mathrm{j}$ for observation $\mathrm{i}, \mathrm{x}_{\mathrm{ij}}$, as a change in $\mathrm{x}_{\mathrm{ij}}$ has an impact on both the mean of $y$, given that it is observed, and an effect on the probability of y being observed. Standard errors in brackets. Asterisks ${ }^{* *},{ }^{* *},{ }^{*}$ denote significance of coefficients at the $1 \%, 5 \%$, and $10 \%$ level, respectively.

\section{Impact of intervention on the level and volatility of exchange rate returns}

26. GARCH estimations were carried out both over the full sample period (January 2001 to May 2008) and for several subperiods. Results for the base model are shown in Table II.3. The first column presents the regression for the full sample; the second column includes the period January 2001 to October 2005, when the CBA conducted interventions primarily on the OTC interbank spot market or through foreign exchange swap arrangements; and the third column contains the estimation results for the most recent period since November 2005, when the CBA shifted its foreign exchange operations to the electronic trading platform at the local stock exchange.

27. Controlling for relative dollar strength, interest differentials, the proxy for capital inflows, and lagged exchange rate changes, the model suggests that foreign exchange purchases may have had a significant impact on exchange rate returns over the entire sample period, and in the second subperiod. However, the respective coefficient consistently has a negative sign, that is, foreign exchange purchases are associated with an appreciation of the domestic exchange rate. This could be an indication of the simultaneity problem discussed 
Table II.3: Impact of CBA Intervention on the Level of the Exchange Rate

\begin{tabular}{|c|c|c|c|}
\hline & $\begin{array}{c}\text { Full sample } \\
\text { Jan. } 2001 \text { - May } 2008\end{array}$ & $\begin{array}{c}\text { First period } \\
\text { Jan. 2001-Oct. } 2005\end{array}$ & $\begin{array}{c}\text { Second period } \\
\text { Nov. } 2005 \text { - May } 2008\end{array}$ \\
\hline \multicolumn{4}{|c|}{ Exchange rate level (mean) equation } \\
\hline $\mathrm{GARCH}$ & $\begin{array}{r}2.897 \\
(14.158)\end{array}$ & $\begin{array}{r}7.102 \\
(15.155)\end{array}$ & $\begin{array}{r}66.462 \\
(40.679)\end{array}$ \\
\hline$\Delta\left(\operatorname{lns}_{\mathrm{t}-1}\right)$ & $\begin{array}{l}0.304^{* * *} \\
(0.036)\end{array}$ & $\begin{array}{l}0.271^{* * *} \\
(0.054)\end{array}$ & $\begin{array}{l}0.499 \text { *** } \\
(0.053)\end{array}$ \\
\hline $\mathrm{I}_{\mathrm{t}-1}$ & $\begin{array}{l}-0.226 \text { ** } \\
(0.112)\end{array}$ & $\begin{array}{r}-0.056 \\
(0.181)\end{array}$ & $\begin{array}{l}-0.193^{* * *} \\
(0.0684)\end{array}$ \\
\hline$I_{t-1}^{S}$ & $\begin{array}{r}-0.028 \\
(0.066)\end{array}$ & $\begin{array}{r}-1.287 \\
(1.042)\end{array}$ & $\begin{array}{r}0.067 \\
(0.116)\end{array}$ \\
\hline$\Delta\left(\operatorname{lne}_{t}\right)$ & $\begin{array}{c}0.018 \text { * } \\
(0.009)\end{array}$ & $\begin{array}{r}0.004 \\
(0.007)\end{array}$ & $\begin{array}{l}0.063^{* * *} \\
(0.017)\end{array}$ \\
\hline$\Delta\left(\mathrm{i}-\mathrm{r}^{*}\right)_{\mathrm{t}-1}$ & $\begin{array}{r}0.000 \\
(0.000)\end{array}$ & $\begin{array}{r}0.000 \\
(0.000)\end{array}$ & $\begin{array}{r}0.000 \\
(0.000)\end{array}$ \\
\hline$\Delta(\mathrm{oil})_{\mathrm{t}-1}$ & $\begin{array}{l}-0.010 \text { * } \\
(0.006)\end{array}$ & $\begin{array}{l}-0.012 \text { * } \\
(0.007)\end{array}$ & $\begin{array}{r}-0.007 \\
(0.018)\end{array}$ \\
\hline \multicolumn{4}{|c|}{ Exchange rate volatility (variance) equation } \\
\hline $\operatorname{RESID}(-1)^{\wedge} 2$ & $\begin{array}{l}0.150 \text { ** } \\
(0.062)\end{array}$ & $\begin{array}{c}0.150 \text { * } \\
(0.090)\end{array}$ & $\begin{array}{l}0.150 \text { *** } \\
(0.037)\end{array}$ \\
\hline $\mathrm{GARCH}(-1)$ & $\begin{array}{l}0.600 \text { *** } \\
(0.035)\end{array}$ & $\begin{array}{l}0.600^{* * *} \\
(0.134)\end{array}$ & $\begin{array}{l}0.600 \\
(0.063)\end{array}$ \\
\hline$\Delta\left(\operatorname{lns}_{\mathrm{t}-1}\right)$ & $\begin{array}{r}0.000 \\
(0.000)\end{array}$ & $\begin{array}{r}0.000 \\
(0.001)\end{array}$ & $\begin{array}{r}0.000 \\
(0.000)\end{array}$ \\
\hline $\mathrm{I}_{\mathrm{t}-1}$ & $\begin{array}{r}0.000 \\
(0.000)\end{array}$ & $\begin{array}{r}0.000 \\
(0.002)\end{array}$ & $\begin{array}{c}0.000 * \\
(0.000)\end{array}$ \\
\hline$I_{t-1}^{S}$ & $\begin{array}{l}-0.001 * * * \\
(0.000)\end{array}$ & $\begin{array}{r}-0.002 \\
(0.003)\end{array}$ & $\begin{array}{l}-0.001^{\text {*** }} \\
(0.000)\end{array}$ \\
\hline$\Delta\left(\operatorname{lne}_{t}\right)$ & $\begin{array}{r}0.000 \\
(0.000)\end{array}$ & $\begin{array}{r}0.000 \\
(0.000)\end{array}$ & $\begin{array}{r}0.000 \\
(0.000)\end{array}$ \\
\hline$\Delta\left(\mathrm{i}-\mathrm{r}^{\star}\right)_{\mathrm{t}-1}$ & $\begin{array}{l}0.000 \text { *** } \\
(0.000)\end{array}$ & $\begin{array}{r}0.000 \\
(0.000)\end{array}$ & $\begin{array}{r}0.000 \\
(0.000)\end{array}$ \\
\hline$\Delta(\mathrm{oil})_{\mathrm{t}-1}$ & $\begin{array}{r}0.000 \\
(0.000)\end{array}$ & $\begin{array}{r}0.000 \\
(0.000)\end{array}$ & $\begin{array}{r}0.000 \\
(0.000)\end{array}$ \\
\hline Day fixed effects & yes & yes & yes \\
\hline $\mathrm{R}^{2}$ & 0.111 & 0.061 & 0.269 \\
\hline $\begin{array}{l}\text { Adj. } R^{2} \\
\text { Log-L } \\
\text { Observations }\end{array}$ & $\begin{array}{l}0.100 \\
9,000 \\
1,934\end{array}$ & $\begin{array}{l}0.045 \\
5,823 \\
1,259\end{array}$ & $\begin{array}{r}0.244 \\
3,267 \\
674\end{array}$ \\
\hline
\end{tabular}

Note: Dependent variable: $\Delta \mathrm{s}_{\mathrm{t}}$. The intervention coefficients represent the impact of a $\$ 1$ million purchase/sale of foreign exchange on the exchange rate. Constant, day-of-the-week, and holiday dummy coefficients not reported. Asterisks ${ }^{* * *},{ }^{* *},{ }^{*}$ denote significance of coefficients at the $1 \%, 5 \%$, and $10 \%$ level, respectively. BollerslevWooldridge robust standard errors and covariance. 
above. Possibly, the causality from exchange rate changes to foreign exchange intervention dominates the reverse effect from intervention to exchange rate changes. Accordingly, the CBA tries to lean against the wind in times of mounting appreciation pressures, but apparently does not succeed in its efforts to moderate the speed of exchange rate adjustment. Foreign exchange sales, on the other hand, do not appear to have a significant impact on exchange rate returns. Possibly, this could be explained by the fact that in recent years, foreign exchange sales were primarily used as an instrument for liquidity management in periods of relative foreign exchange market calm rather than to support the exchange rate.

28. Regarding the impact of foreign exchange intervention on the volatility of the exchange rate, the model indicates that foreign exchange sales are associated with lower exchange rate volatility. This, however, may again be due to the above observation that foreign exchange sales have been largely undertaken (for liquidity management purposes) in periods of low exchange rate volatility in the first place. When it comes to foreign exchange purchases, hardly any impact can be detected, but foreign exchange purchases appear to have been associated with slightly higher volatility in the second subperiod.

29. The control variables generally have the theoretically expected impact on the exchange rate. The autoregressive term is consistently positive and significant in the mean equation, relative dollar strength depreciates the domestic currency, and rising capital inflow pressures are associated with an appreciation of the dram. The exchange rate does not appear to be sensitive to interest differentials, which is not surprising given the lack of significant portfolio flows and of domestic financial investment instruments. Generally, the model explains exchange rate returns much better in the second period than in the first period, possibly owing to a gradual deepening of the foreign exchange market in recent years.

30. In an alternative model approach, exchange rate returns are replaced by deviations of the dram/dollar exchange rate from trend, derived using a Hodrick-Prescott filter (Table II.4). Here, negative deviations represent faster-than-usual dram appreciation, and positive values depreciation or a short-term slowing of appreciation compared to trend. The theoretically expected signs of interventions remain the same compared to the original model: If effective, foreign exchange purchases (sales) would again depreciate (appreciate) the exchange rate relative to trend. 
Table II.4: Impact of CBA Intervention on Deviations from Exchange Rate Trend

\begin{tabular}{|c|c|c|c|}
\hline & $\begin{array}{c}\text { Full sample } \\
\text { Jan. } 2001 \text { - May } 2008\end{array}$ & $\begin{array}{c}\text { First period } \\
\text { Jan. 2001-Oct. } 2005\end{array}$ & $\begin{array}{c}\text { Second period } \\
\text { Nov. } 2005 \text { - May } 2008\end{array}$ \\
\hline \multicolumn{4}{|c|}{ Exchange rate level (mean) equation } \\
\hline GARCH & $\begin{array}{r}0.030 \\
(0.027)\end{array}$ & $\begin{array}{r}0.041 \\
(0.043)\end{array}$ & $\begin{array}{l}-0.1344^{* * *} \\
(0.049)\end{array}$ \\
\hline $\mathrm{HP} \Delta \mathrm{s}_{\mathrm{t}-1}$ & $\begin{array}{l}0.999^{* * *} \\
(0.004)\end{array}$ & $\begin{array}{l}0.998^{* * *} \\
(0.006)\end{array}$ & $\begin{array}{l}0.978^{* * *} \\
(0.005)\end{array}$ \\
\hline$P_{t-1}^{P}$ & $\begin{array}{l}-75.313^{* \star \star} \\
(21.687)\end{array}$ & $\begin{array}{r}-24.017 \\
(72.755)\end{array}$ & $\begin{array}{l}-107.003^{* * *} \\
(31.183)\end{array}$ \\
\hline $\mathrm{I}_{\mathrm{t}-1}^{\mathrm{S}}$ & $\begin{array}{l}87.681^{* * *} \\
(20.077)\end{array}$ & $\begin{array}{r}-33.316 \\
(354.055)\end{array}$ & $\begin{array}{r}98.616 \\
(67.993)\end{array}$ \\
\hline$\Delta\left(\operatorname{lne}_{t}\right)$ & $\begin{array}{r}5.072 \\
(3.278)\end{array}$ & $\begin{array}{r}3.792 \\
(8.999)\end{array}$ & $\begin{array}{l}18.770^{* * *} \\
(6.618)\end{array}$ \\
\hline$\Delta\left(\mathrm{i}-\mathrm{r}^{*}\right)_{\mathrm{t}-1}$ & $\begin{array}{r}-0.002 \\
(0.019)\end{array}$ & $\begin{array}{r}-0.041 \\
(0.026)\end{array}$ & $\begin{array}{r}-0.138 \\
(0.093)\end{array}$ \\
\hline$\Delta(\mathrm{oil})_{\mathrm{t}-1}$ & $\begin{array}{l}-6.026 \text { * } \\
(3.265)\end{array}$ & $\begin{array}{l}-11.276 \text { *** } \\
(3.430)\end{array}$ & $\begin{array}{r}-5.738 \\
(4.011)\end{array}$ \\
\hline \multicolumn{4}{|c|}{ Exchange rate volatility (variance) equation } \\
\hline $\operatorname{RESID}(-1)^{\wedge} 2$ & $\begin{array}{l}0.259^{* * *} \\
(0.073)\end{array}$ & $\begin{array}{l}0.191 \text { * } \\
(0.118)\end{array}$ & $\begin{array}{l}0.094^{* *} \\
(0.073)\end{array}$ \\
\hline $\mathrm{GARCH}(-1)$ & $\begin{array}{l}0.532 \text { *** } \\
(0.038)\end{array}$ & $\begin{array}{l}0.5422^{* * *} \\
(0.169)\end{array}$ & $\begin{array}{l}0.484 \text { *** } \\
(0.154)\end{array}$ \\
\hline $\mathrm{HP} \Delta \mathrm{s}_{\mathrm{t}-1}$ & $\begin{array}{l}-0.012 \text { *** } \\
(0.002)\end{array}$ & $\begin{array}{l}-0.008^{* * *} \\
(0.117)\end{array}$ & $\begin{array}{r}0.001 \\
(0.006)\end{array}$ \\
\hline $\mathrm{I}_{\mathrm{t}-1}$ & $\begin{array}{l}-0.019 \\
(0.078)\end{array}$ & $\begin{array}{l}-0.081 \\
(0.117)\end{array}$ & $\begin{array}{l}-0.004 \\
(0.060)\end{array}$ \\
\hline $\mathrm{I}_{\mathrm{t}-1}^{\mathrm{S}}$ & $\begin{array}{l}-0.234^{* * *} \\
(0.023)\end{array}$ & $\begin{array}{r}-0.479 \\
(0.984)\end{array}$ & $\begin{array}{r}-0.073 \\
(0.078)\end{array}$ \\
\hline$\Delta\left(\operatorname{lne}_{\mathrm{t}}\right)$ & $\begin{array}{l}-6.809^{* *} \\
(3.155)\end{array}$ & $\begin{array}{r}-4.127 \\
(11.243)\end{array}$ & $\begin{array}{r}-6.133 \\
(8.675)\end{array}$ \\
\hline$\Delta\left(\mathrm{i}-\mathrm{r}^{\star}\right)_{\mathrm{t}-1}$ & $\begin{array}{l}0.052 \text { ** } \\
(0.026)\end{array}$ & $\begin{array}{r}-0.095 \\
(0.074)\end{array}$ & $\begin{array}{r}-0.038 \\
(0.133)\end{array}$ \\
\hline$\Delta(\mathrm{oil})_{\mathrm{t}-1}$ & $\begin{array}{r}-1.009 \\
(1.853)\end{array}$ & $\begin{array}{r}4.027 \\
(5.445)\end{array}$ & $\begin{array}{r}-0.020 \\
(3.701)\end{array}$ \\
\hline Day fixed effects & yes & yes & yes \\
\hline$R^{2}$ & 0.962 & 0.957 & 0.976 \\
\hline Adj. $R^{2}$ & 0.962 & 0.956 & 0.975 \\
\hline Log-L & $-2,696$ & $-1,958$ & -780 \\
\hline Observations & 1,934 & 1,259 & 674 \\
\hline
\end{tabular}

Note: Dependent variable: HPAs $\mathrm{s}_{\mathrm{t}}$. The intervention coefficients represent the impact of a $\$ 1$ million purchase/sale of foreign exchange on the exchange rate. Constant, day-of-the-week, and holiday dummy coefficients not reported. Asterisks ${ }^{* * *},{ }^{* *},{ }^{*}$ denote significance of coefficients at the $1 \%, 5 \%$, and $10 \%$ level, respectively. BollerslevWooldridge robust standard errors and covariance. 
31. The estimation results of this alternative model are similar to the original model: counter to intuition, foreign exchange purchases are associated with an appreciation rather than depreciation of the dram/dollar exchange rate, while - at least over the full sample period - foreign exchange sales seem to go hand-in-hand with exchange rate depreciation. Again, interventions appear to follow exchange rate movements rather than inducing them, and they appear not to be able to push the exchange rate in the intended direction. As in the first model, foreign exchange sales are associated with slightly lower exchange rate volatility. The coefficient of foreign exchange purchases also appears with a negative sign in the variance equation, but is never significant.

32. Overall, the GARCH estimation results presented above are largely robust to modifications in model specification. While some results vary slightly, the choice of sample periods, use of alternative GARCH model variants, inclusion or exclusion of individual control variables, and varying choices of lag length of the autoregressive term or the intervention variables, leave the main results unchanged: interventions appear not to result in exchange rate movements in the intended direction and have only a very limited impact on the volatility of the exchange rate.

\section{Consistency of Exchange Rate and Monetary Policies}

33. Monetary policy effectiveness in recent years has been limited by unstable money demand against the backdrop of significant shifts in monetization and dollarization. In response to these constraints, the CBA has been gradually shifting from a monetary anchor to an inflation targeting regime since 2006, with the forecast level of inflation as the intermediate target and the short-term interest rate as the main operational target. However, the monetary transmission mechanism has remained relatively weak owing to the limited depth of financial markets and substantial excess liquidity in the banking system. Between 2005 and 2007, the CBA issued significant amounts of its own short-term securities to mop up excess liquidity. Foreign exchange sales supplemented these efforts during times of relative foreign exchange market calm, usually during the first quarter of the year.

34. Armenia has experienced a credit boom since the second half of 2007, mostly driven by the need to finance imports, consumption, and the real-estate market. This credit surge was triggered by strong economic growth, rising incomes, and an appreciated currency, and supported by a much-improved financial infrastructure and large-scale inflows of foreign bank capital. The sudden increase in private sector credit growth resulted in a substantial financial deepening and diminished excess bank reserves, but also increased domestic demand pressures in an environment of rising inflation driven by a surge in international food and energy prices. At the same time, rapidly growing remittance and capital inflows maintained considerable upward pressure on the exchange rate. This led both to increasing concerns about external competitiveness and to increased uncertainty, as large-scale and 
lumpy foreign exchange inflows triggered several sharp appreciation rallies, which were reinforced by substantial conversions of deposits and cash dollar holdings into dram.

35. While most of the economic developments described above are welcome-rising incomes, investment, and consumption; financial deepening; and the strengthening of a previously depreciated exchange rate which contributed to lower inflation compared to neighboring countries - they have also complicated monetary management. The monetary authorities are now facing challenging trade-offs: the CBA needs to balance the need to maintain macroeconomic stability and reduce inflation with the need to preserve external competitiveness and the value of still substantial foreign-currency assets of households.

36. On the domestic front, the CBA began to tighten monetary policy by steadily raising the policy interest rate. At the same time, however, it substantially increased foreign exchange interventions. These interventions injected liquidity through largely unsterilized foreign exchange purchases, amounting to about 90 percent of end-2006 reserve money, thereby driving rapid reserve money growth (Figure II.4, top panels).

Figure II.4. Armenia: Intervention, Money Growth, and Inflation

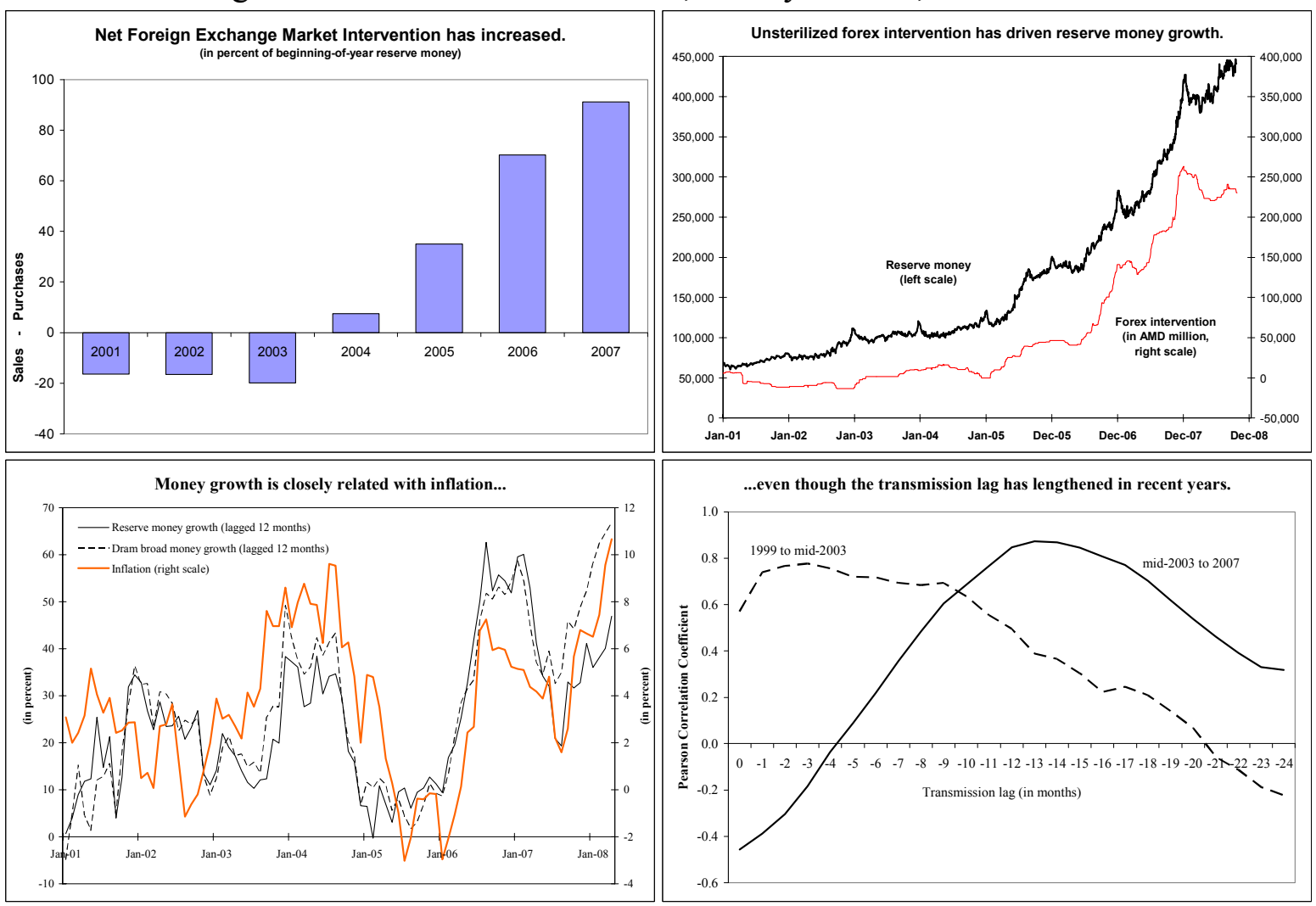

Sources: Central Bank of Armenia; and author's calculations. 
37. The surplus liquidity contributed to blunting the interest rate channel of monetary policy. Commercial banks did not begin to raise lending rates until the third quarter of 2008, more than a year after the CBA commenced with its gradual increases in the repo rate. While part of foreign exchange market interventions have accommodated cash dedollarization, liquidity injections through unsterilized interventions are also likely to have fuelled credit growth and domestic demand. With an approximate transmission lag from money growth to inflation of about a year, this may lead to additional inflation pressures in the period ahead (Figure II.4, bottom panel).

38. This temporary inconsistency between the CBA's inflation targeting strategy and foreign exchange market intervention has been resolved in 2008. Foreign exchange market interventions (foreign exchange sales) and interest rate increases have been consistent, resulting both in a tightening of the monetary policy stance.

\section{E. Conclusion}

39. This paper analyzed the impact of CBA interventions in the foreign exchange market from 2001 to 2008. The main focus was on investigating the effectiveness of foreign exchange purchases and sales in moderating the extent and volatility of exchange rate changes. Subsequently, the paper discussed trade-offs between inflation targeting and exchange rate policy objectives and possible inconsistencies between the monetary and intervention policies followed in the recent past.

40. To examine the effectiveness of interventions, a two-stage approach was employed. The first step involved modeling the intervention policy reaction function of the central bank. In the second step, the intervention forecasts of the first stage were employed as instruments in a GARCH model of the level and volatility of dram/dollar exchange rate returns.

41. The results of the empirical investigation lend only weak support to the hypothesis that foreign exchange interventions have been effective in Armenia. While the incidence and size of foreign exchange interventions can be fairly well predicted by short- and mediumterm exchange rate movements as well as prior intervention activity, the evidence regarding the impact of intervention on exchange rate returns is rather weak. In particular, where intervention coefficients were found statistically significant in the mean equation, the effects were small and not in the theoretically expected direction. As regards the variance equation, the model indicates that foreign exchange sales may have some limited impact on lowering the volatility of exchange rate returns.

42. However, these findings should be treated with caution. First, there are some methodological challenges, primarily the difficulty to disentangle cause and effect due to the identification problem resulting from the simultaneity of exchange rate changes and intervention activity. Second, it may well be that foreign exchange interventions have had stabilizing intra-day effects - in particular in the context of very volatile market activity and 
lumpy foreign exchange flows. Intraday effects of foreign exchange intervention - which in turn could possibly create additional interday exchange rate dynamics - cannot be investigated in the current study due to the lack of ultra-high frequency data.

43. Regarding the issue of monetary and exchange rate policy consistency, it was argued that large-scale unsterilized foreign exchange interventions have contradicted the monetary tightening pursued to fight rising inflation pressures in 2006 and particularly the second half of 2007. While partly accommodating cash dollarization, the injection of large amounts of domestic currency liquidity into the market may have blunted the interest rate channel of monetary policy, has fuelled money and credit growth, and may eventually result in higher inflation from domestic demand pressures. 


\section{REFERENCES}

Akinzi, Ö., O. Y. Çulha, Ü. Özlale, G. Şahinbeyoğlu, 2005, “Causes and Effectiveness of Foreign Exchange Interventions for the Turkish Economy," Central Bank of Turkey Research Department Working Paper No. 5 (Ankara: Central Bank of the Republic of Turkey).

Atoyan, Ruben, and Nienke Oomes, 2006, "Remittances to Armenia: Size, Sources, and Macroeconomic Implications," Republic of Armenia: Selected Issues, IMF Country Report, No. 06/434, pp. 4-16 (Washington: International Monetary Fund).

Bollerslev, Tim, 1986, “Generalized Autoregressive Conditional Heteroskedasticity,” Journal of Econometrics, Vol. 21, pp.307-327.

Canales-Kriljenko, Jorge Iván, 2003, “Foreign Exchange Intervention in Developing and Transition Economies: Results of a Survey," IMF Working Paper 03/95 (Washington: International Monetary Fund).

Disyatat, Piti, and Gabriele Galati, 2007, "The Effectiveness of Foreign Exchange Intervention in Emerging Market Countries: Evidence from the Czech Koruna," Journal of International Money and Finance, Vol. 26, pp. 383-402.

Domac, Ilker, and Alfonso Mendoza, 2002, "Is there Room for Forex Intervention under Inflation Targeting Framework? Evidence from Mexico and Turkey," Central Bank of Turkey Discussion Paper No. 58 (Ankara: Central Bank of the Republic of Turkey).

Dominguez, Kathryn M., and Jeffrey Frankel, 1993, "Does Foreign Exchange Intervention Work?," (Washington, D.C.: Institute for International Economics).

Dominguez, Kathryn M., 2003, "The Market Microstructure of Central Bank Intervention," Journal of International Economics, Vol. 59, pp. 25-45.

Égert, Balázs, and Luboš Komárek, 2006, "Foreign Exchange Interventions and Interest Rate Policy in the Czech Republic: Hand in Glove?," Economic Systems, Vol. 30, pp. 121140.

Fratzscher, M., 2005, "How Successful are Exchange Rate Communication and Interventions? Evidence from Time Series and Event Study Approaches," ECB Working Paper No. 528 (Frankfurt a. M.: European Central Bank).

Guimarães, Roberto, and Cem Karacadag, 2004, "The Empirics of Foreign Exchange Intervention in Emerging Market Countries: The Cases of Mexico and Turkey," IMF Working Paper 04/123 (Washington: International Monetary Fund). 
Herrera, A. M., and P. Özbay, 2005, “A Dynamic Model of Central Bank Intervention,” Central Bank of Turkey Research Department Working Paper No. 1 (Ankara: Central Bank of the Republic of Turkey).

International Monetary Fund, 2006, "Republic of Armenia—Staff Report for the 2006 Article IV Consultation and Third Review Under the Poverty Reduction and Growth Facility,” IMF Country Report 06/141 (Washington: International Monetary Fund).

Ito, Takatoshi, 2002, "Is Foreign Exchange Intervention Effective? The Japanese Experiences in the 1990s," NBER Working Paper 8914 (Cambridge, Massachusetts: MIT Press).

Kamil, Herman, 2008, "Is Central Bank Intervention Effective Under Inflation Targeting Regimes? The Case of Colombia," IMF Working Paper 08/88 (Washington: International Monetary Fund).

Neely, C. J., 2005, “An Analysis of Recent Studies of the Effect of Foreign Exchange Intervention,” Federal Reserve Bank of St. Louis Working Paper No. 87 (St. Louis: Federal Reserve Bank of St. Louis), pp. 685-718.

Tapia, M., and A. Tokman, 2004, Effects of Foreign Exchange Interventions under Public Information: The Chilean Case," Central Bank of Chile Working Paper No. 225 (Santiago, Central Bank of Chile).

Taylor, S., 1986, Modeling Financial Time Series (New York: John Wiley \& Sons). 


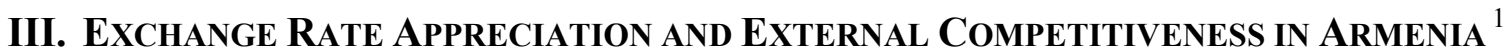

\section{A. Introduction}

1. In recent years, the significant appreciation of the dram has raised concerns about the competitiveness of the Armenian economy. While the dram is expected to appreciate as incomes and productivity in Armenia rise, large foreign exchange inflows have led to concerns about a possible overvaluation of the dram. The dramatic appreciation already appears to have had adverse effects on the current account, as well as on households who receive remittances in dollars.

2. This chapter assesses the degree of external and domestic competitiveness of the Armenian economy. Section B begins by discussing recent external developments. This is followed in Section $\mathrm{C}$ by a summary of four different equilibrium exchange rate estimates, based on the purchasing power parity (PPP) approach, the behavioral equilibrium exchange rate (BEER) approach, the external sustainability (ES) approach, and the macroeconomic balance (MB) approach. Section D assesses domestic competitiveness by estimating the degree of exchange rate pass-through to import prices, which can be considered a measure of the degree of domestic competitiveness in Armenia. Section E discusses structural competitiveness. Section F concludes.

3. The chapter offers three main conclusions. First, all four approaches for estimating the equilibrium real exchange rate suggest that the recent dramatic appreciation has reduced the previously existing undervaluation and has brought the real exchange rate back to (and possibly slightly above) equilibrium. Second, the pass-through estimates point to significant downward rigidity in import prices in response to exchange rate movements, suggesting that there may be insufficient domestic competition between importers. Third, an acceleration of structural reforms is needed to maintain competitiveness in Armenia.

\section{B. Recent External Developments}

4. Armenia's net international investment position (NIIP) has improved. Net external liabilities have declined steadily over the past five years and compare favorably with neighboring countries (Figure III.1). Armenia's NIIP stood at negative 7 percent of GDP as of end 2007.

\footnotetext{
${ }^{1}$ Prepared by Reginald Darius, drawing extensively from Oomes, Gonçalves, and Minasyan, 2008.
} 
Figure III.1. Armenia: Net Investment Position (Percent of GDP)

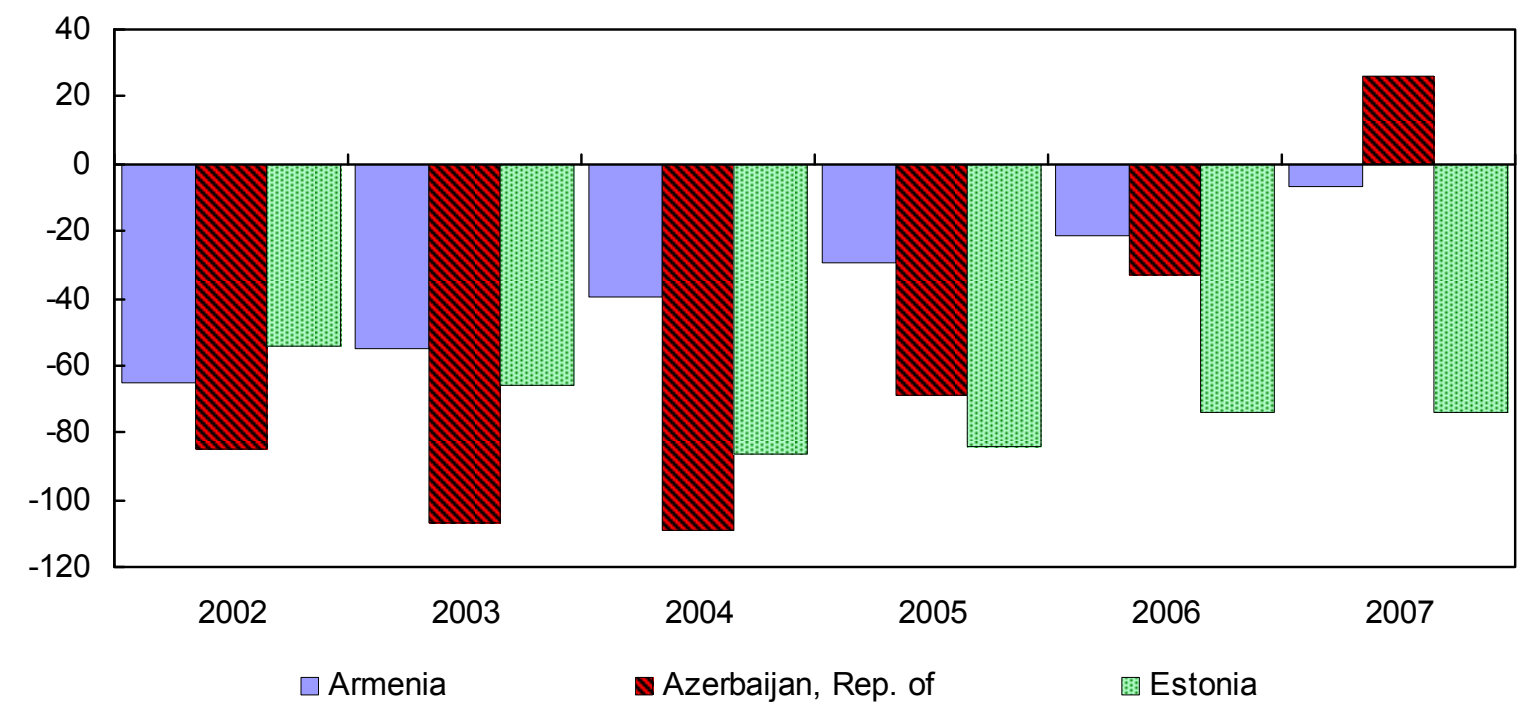

Sources: IFS; and Fund staff estimates.

5. While the current account deficit narrowed significantly between 1998 and 2004, it has widened again in recent years. Armenia's external balance has deteriorated amid strong currency appreciation and a surge in imports. Although remittance flows continued to provide a strong boost to the current account in 2006-07, the underlying trade deficit worsened. This reflected a surge in import demand associated with buoyant economic activity and relatively tepid export performance (Figure III.2).

Figure III.2. Armenia: External Balance (In percent of GDP)

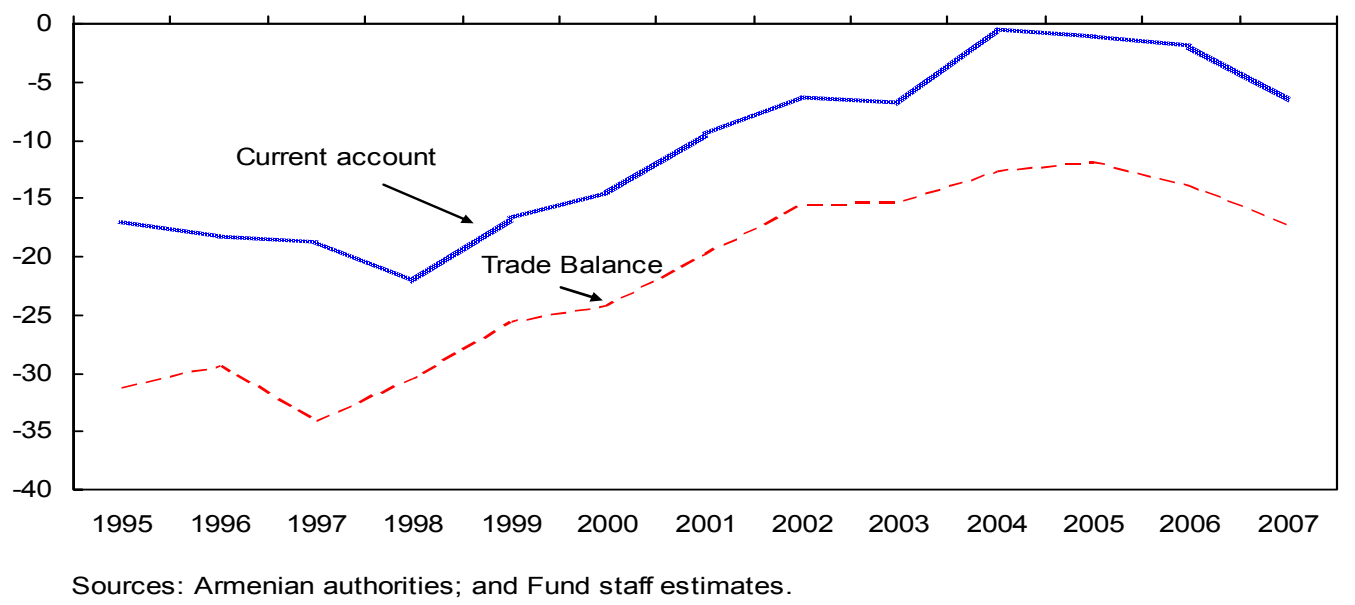

6. One of the possible reasons for the deteriorating trade balance in recent years is the fact that the real exchange rate has appreciated sharply during this period. The CPI-based REER shows a cumulative real appreciation of about 35 percent from 1995 to 2007, 
indicating a possible worsening of Armenia's competitiveness (Figure III.3). Changes in the REER were driven by strong appreciation of the nominal effective exchange rate (NEER). REER developments can be examined within three distinct periods:

Figure III.3. Armenia: REER and NEER (1995-2007)

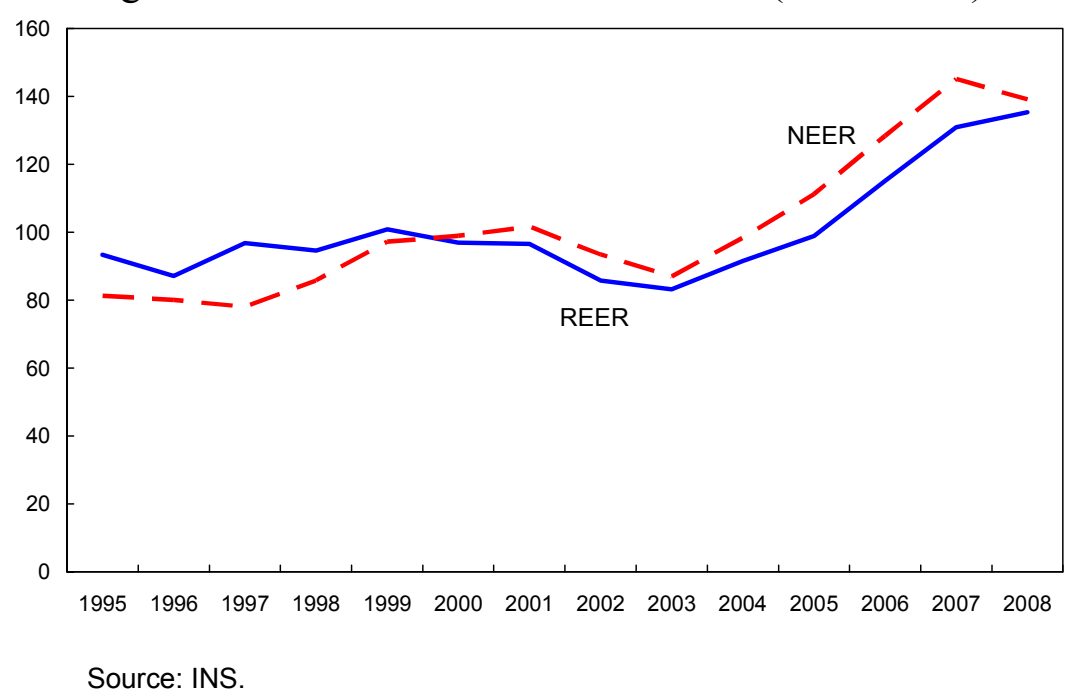

- 1995-1998: Armenia experienced an average annual appreciation of about 2 percent.

- 1999-2002: A depreciation of about 4 percent reversed the appreciation of the proceeding period.

- $\quad$ Since 2003: Through end-2007, Armenia's REER appreciated by 12 percent. From end 2007 to July 2008 the currency appreciated by an additional 3 percent.

7. Another indication of a possible deterioriation in competitiveness is that unit labor costs have increased. The period of relatively rapid REER appreciation coincided with a gradual and steady increase in unit labor costs, driven by a steep increase in wages in agriculture and - to a lesser extent - in industry (Figure III.4). This possibly contributed to weakening external competitiveness. However, labor market data for Armenia are not very reliable, due in part to the large size of the informal economy and the common practice to underreport wages. Thus, the observed increase in wages may also be, in part, the result of a reduction in the extent to which wages are underreported. 
Figure III.4. Armenia:Unit Labor Costs: Average Annual Wage Bill / Nominal GDP (in AMD)

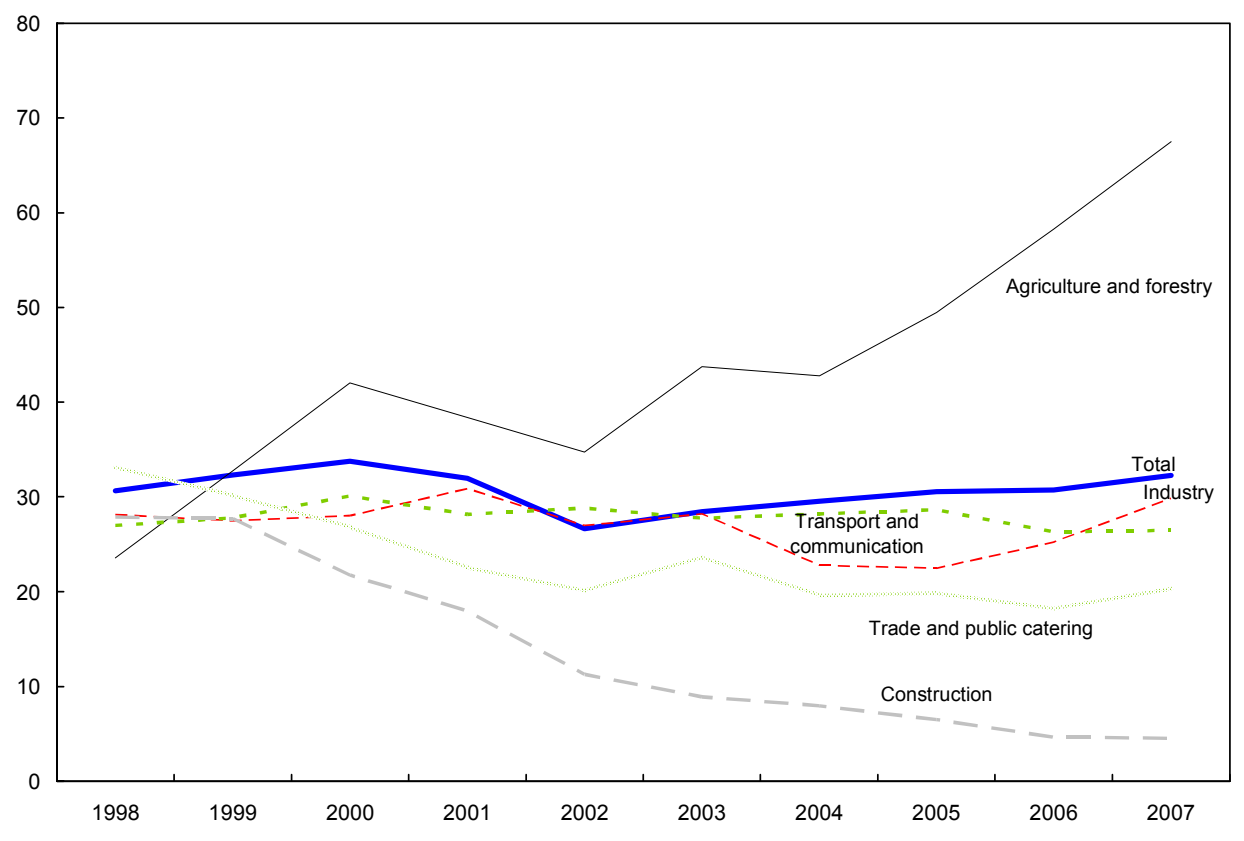

\section{Exchange Rate Assessment}

8. The recent significant appreciation of the dram has raised concerns about export competitiveness. To ascertain whether dram appreciation has resulted in an overvaluation of the real exchange rate, estimates of the equilibrium real exchange rate are derived using three differing approaches. Estimates of the current account norm derived from the macroeconomic balance approach are also presented in this section.

\section{Purchasing Power Parity (PPP) approach}

9. Recent PPP estimates (based on 2005 weights) suggest that Armenian prices in U.S. dollar terms increased from about one third to more than one half of U.S. dollar prices, during the past five years (Figure III.5). Assuming that a relative price of 100 percent (PPP exchange rate of one) was defined as the equilibrium real exchange rate, these PPP estimates would imply a dram undervaluation of about 50 percent. However, it would be more reasonable to estimate the "equilibrium distance to PPP," which would take into account the fact that prices are generally lower in countries with lower incomes and productivity. In the spirit of Balassa (1964) and Samuelson (1964), this implies that we expect the real exchange rate to appreciate in line with the "relative productivity differential." 
Figure III.5. Armenia: Local Price Level Relative to U.S. Price Level (In percent)

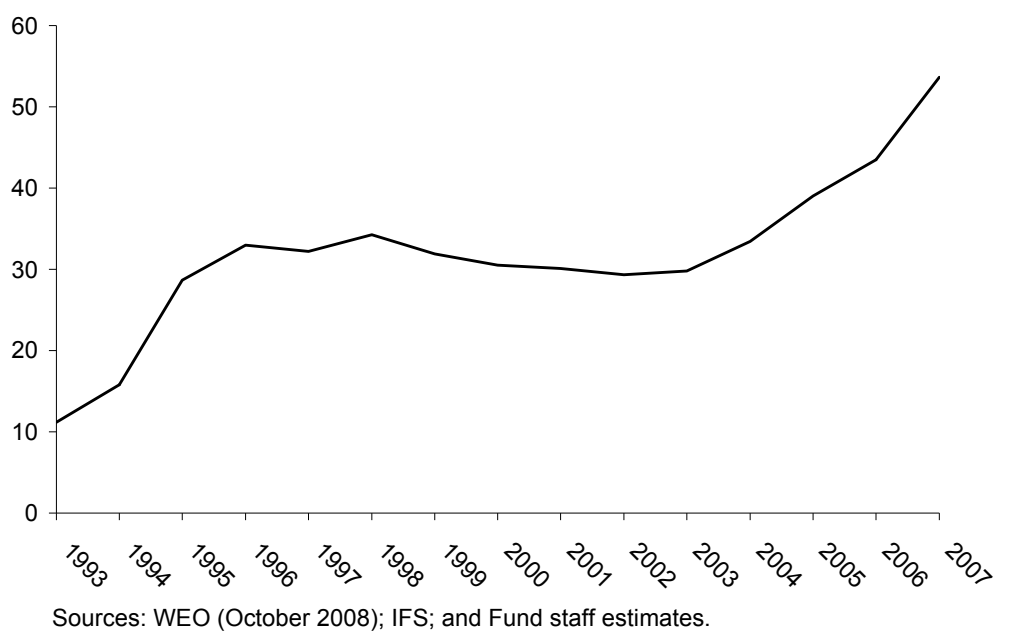

10. Consistent with the Balassa-Samuelson hypothesis, the data in Figure III.6 show a positive relationship between the real exchange rate and productivity (proxied by GDP per capita), based on a broad sample of 180 countries. A simple regression shows that, on average, every 1 percent increase in PPP GDP per capita is associated with a real appreciation of 0.39 percent. This result is broadly consistent with that obtained by Rogoff (1996) and De Broeck and Slok (2001). ${ }^{2}$

Figure III.6. Armenia: Relative Price Levels and Relative Incomes (2004)

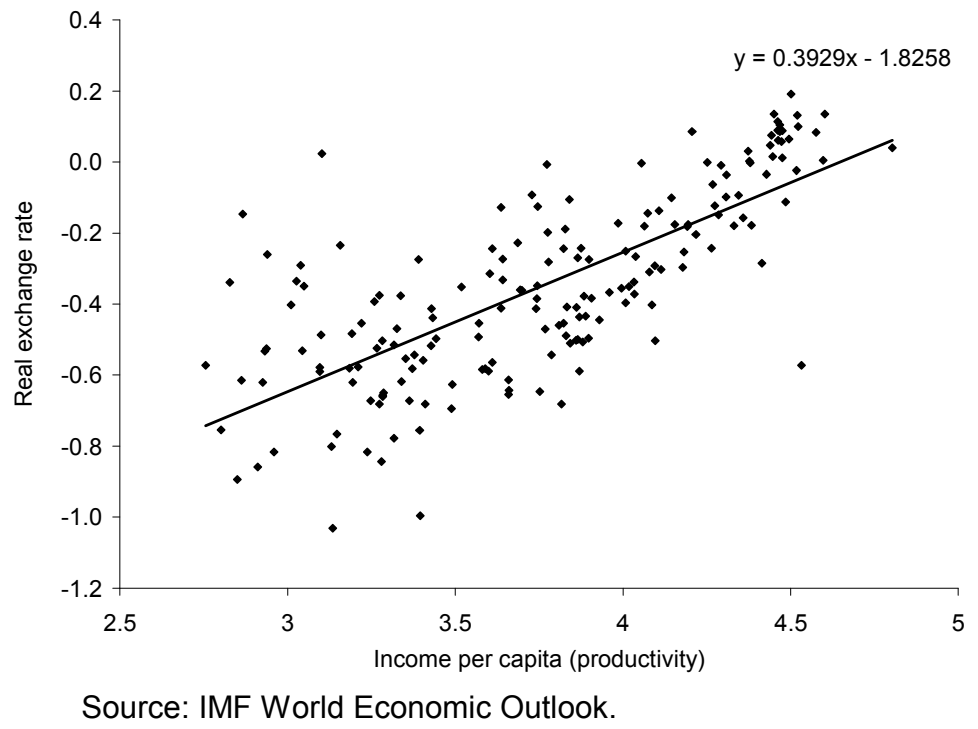

\footnotetext{
${ }^{2} \log ($ real exchange rate $)=-1.83+0.39 * \log ($ PPP GDP per capita). The real exchange rate is measured as the relative price level PE/P*, and productivity is measured as PPP GDP per capita. The sample is taken from the IMF's WEO database and covers 180 countries. Note that, since the data are in logs, a value of 0 on the $y$-axis in Figure III.6 corresponds to full PPP.
} 
11. The results from the PPP estimates suggest that, as of end-2007, the dram was slightly overvalued (Figure III. 7). The PPP estimate of dram misalignment is obtained by comparing the actual real exchange rate (relative price level) with the estimated equilibrium relationship between relative price levels and productivity differentials. The results, shown in Figure 7, suggest that the dram was highly undervalued in 1993, then converged quickly to equilibrium, and remained above equilibrium until after 2000. It then became slightly undervalued during 2002 and 2003, then converged back to equilibrium around 2005, after which it became slightly overvalued.

Figure III.7. Armenia: Equilibrium and Actual Real Exchange Rate (PPP approach) (In Percent)

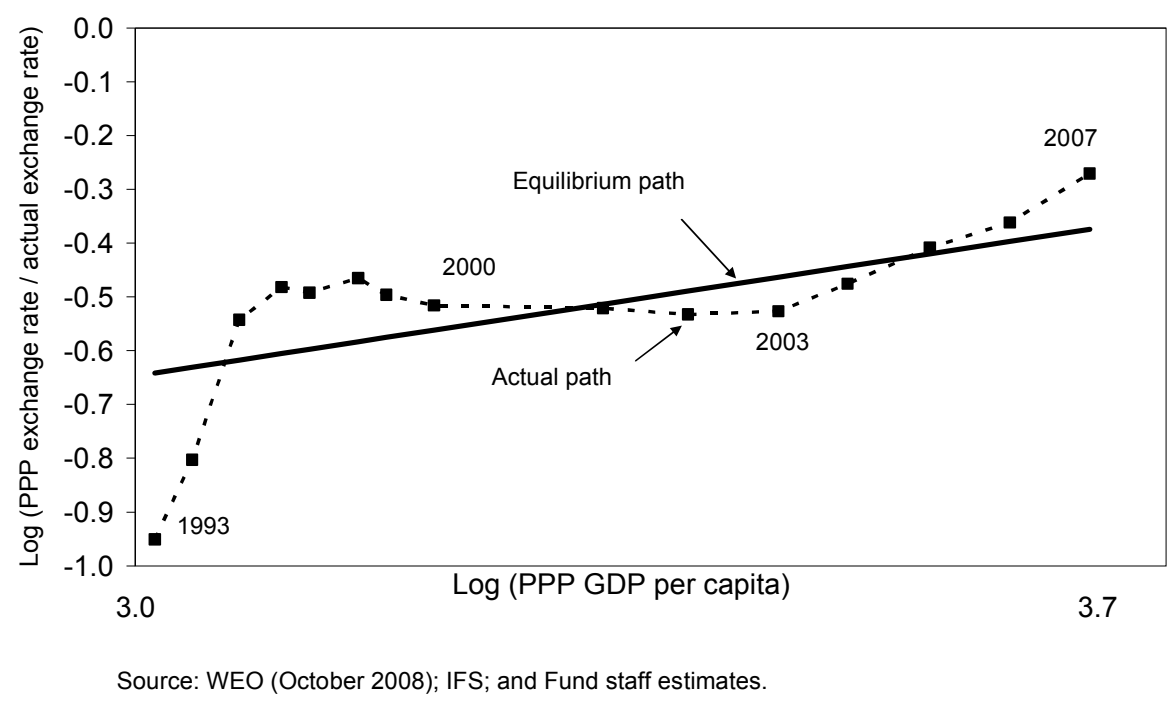

\section{Behavioral Equilibrium Real Exchange Rate (BEER) approach}

12. Another approach for estimating the equilibrium real exchange rate is by using a vector auto regression model and estimating a cointegrating relationship between the REER and its main determinants. The determinants of the REER used in the model include: productivity differential ${ }^{3}$, net international reserves, and government consumption as a percent of GDP. An increase in government consumption (in percent of GDP) is expected to give rise to a real appreciation. While the relationship between NIR and the real exchange

\footnotetext{
${ }^{3}$ Since the EU is Armenia's largest trading partner (accounting for 37 percent of external trade), Armenia's relative productivity differential is computed by comparing it to that of the EU. Other trade partners were not included due to data limitations and differences in sectoral classification.
} 
rate is generally ambiguous, it is likely to be positive for Armenia. ${ }^{4}$ The terms of trade, which are often included in BEER models, are omitted from the estimates, since they tend to be exceedingly volatile in small open economies with an undiversified commodity export base. Furthermore, the terms of trade are likely to be correlated with NIR.

13. The measure of "relative productivity differential" can differ according to the classification of sectors as tradable or nontradable. Industrial production is traditionally considered as tradable, and services as nontradable. However, the classification of other sectors, in particular agriculture, is more ambiguous. Since construction could be considered as either nontradable or tradable, following De Broek and Slok (2001), and Coricelli and Jazbec (2001), separate estimates were derived using the alternative measures of productivity.

14. The results from the BEER approach are consistent with that of the PPP approach, in that they suggest that the real exchange rate is currently near or possibly slightly above equilibrium (Figure III.8). A number of alternative specifications were estimated, generating broadly consistent results on the degree of misalignment. The estimated cointegration vectors indicated that all the dependent variables were statistically significant and of the correct sign.

Figure III.8. Armenia: Actual and Estimated Equilibrium REER (Equation 1)

(1997=100, in logarithms)

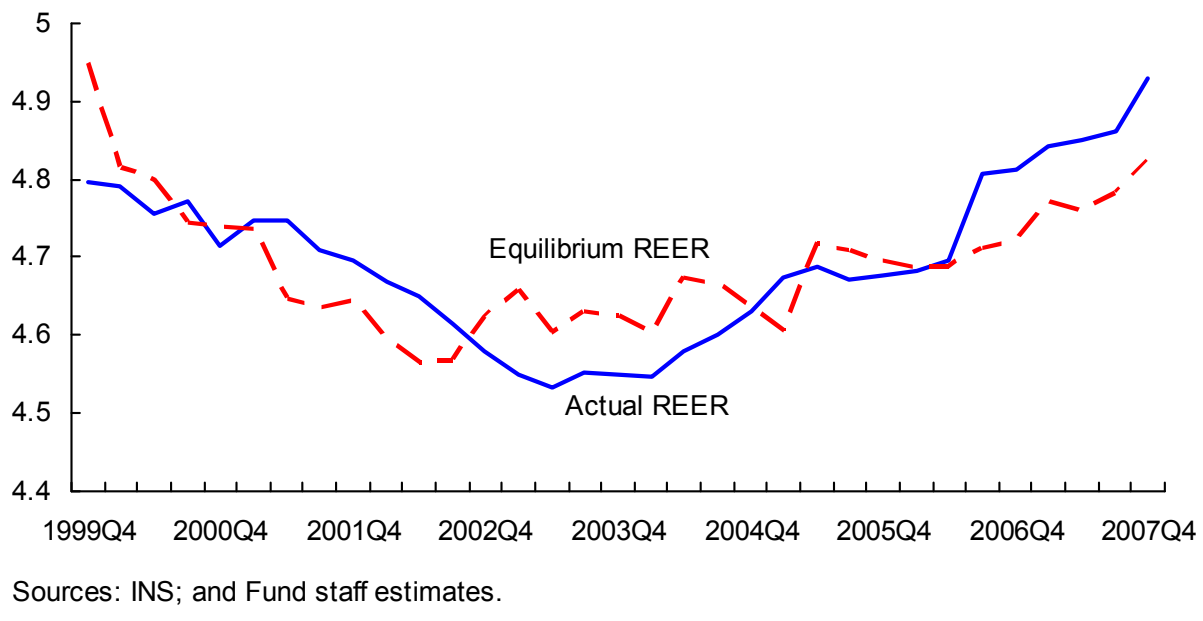

\footnotetext{
${ }^{4}$ As Egert (2003) has argued, transition countries that are still in the catch-up process are likely to have a negative steady-state NIR position, as they finance their growth via foreign capital. While Egert's arguments are for Net Foreign Assets (NFA), NFA of the Central Bank in Armenia is equivalent to NIR.
} 


\section{External Sustainability (ES) approach}

15. A third approach for estimating the equilibrium exchange rate is the external sustainability (ES) approach, which focuses on the relation between the sustainability of a country's external stock position, its current account position, and the real exchange rate. The ES approach consists of a simple calibration exercise that requires only a few assumptions about the economy's potential growth rate, inflation rate, and rates of return on external assets and liabilities.

16. The macroeconomic assumptions underlying the estimates are as follows:

- $\quad$ The choice of the NFA/GDP ratio benchmark is a key element of the ES approach but is, to some extent, arbitrary. For the purposes of this analysis, the NFA/GDP position as of end-2006 (-24.2 percent), was used as the benchmark.

- $\quad$ The inflation rate of NFA is assumed to be 2.5 percent.

- The benchmark GDP growth rate is assumed at 6 percent. To reflect the sensitivity of the estimates to growth assumptions, two alternative scenarios were considered: a low-growth scenario (3 percent), and a high-growth scenario (9 percent).

17. For each of the growth scenarios, the current account deficit required to stabilize the NFA/GDP ratio is as follows:

$>$ benchmark growth:-1.9 percent

low growth: -1.3 percent

high growth: -2.5 percent.

18. Like the PPP and the BEER approaches, the ES approach suggests that the real exchange rate is no longer undervalued, and may have become somewhat overvalued in 2007. The required REER adjustment is broadly similar across the three scenarios. The magnitude of the required exchange rate adjustment is obtained by first computing the elasticity of the current account balance with respect to the real exchange rate.

\section{Macroeconomic Balance (MB) approach $^{5}$}

19. The MB approach adapts the Consultative Group on Exchange Rate Issues (CGER) formulation to fit data availability constraints and economic characteristics of the Armenia

\footnotetext{
${ }^{5}$ This section draws on IMF, 2008.
} 
economy. This version of the MB specification relates the current account (dependent variable) to the fiscal balance, demographics, initial net foreign asset position, oil prices/terms of trade, output growth, and relative income (compared to the U.S.). For non-oil countries such as Armenia, the specification was augmented by adding the real exchange rate and FDI as explanatory variables.

20. Six estimates of the current account "norm" are obtained, ranging from a deficit of about 2 percent GDP to a deficit of 14 percent of GDP. The actual current account level is within the range suggested by these estimates and therefore suggests that the exchange rate was near the equilibrium level. The underlying current account was estimated at a deficit of 5 percent of GDP in 2006. Each specification was estimated using pooled OLS, fixed effects, and GMM estimators. In addition, each specification was estimated - using all three estimation techniques - with the variables expressed as deviations from partner-country averages as well as in (log) levels.

\section{Exchange Rate Pass-Through and Domestic Competition}

21. There is widespread anecdotal evidence of monopolistic practices in some key import sectors, such as sugar and fuel. This section examines whether monopolistic behavior impacts on the pass-through from exchange rate changes to the domestic price of imported goods. The methodology employed loosely follows the vector autoregressive (VAR) model of McCarthy (2007), using monthly data for the period May 2005 - August 2007 (thus excluding the prestabilization period).

22. The VAR specification has four endogenous variables: price of oil in domestic currency, output gap, ${ }^{6}$ nominal effective exchange rate, and import prices. Variables are expressed in first differences to guarantee stationarity and are expressed in natural logs (except for the output gap which is already stationary and can be negative). The rationale for the other variables in the model and their ordering is the following: the oil price identifies supply shocks, while the output gap identifies demand shocks. The exchange rate is therefore allowed to respond contemporaneously to supply and demand shocks. The import price index responds contemporaneously not only to supply and demand shocks, but also to exchange rate shocks.

23. The estimates show that import price responses are much larger for exchange rate depreciations than for appreciations (Figure III.9). Furthermore, only the responses to exchange rate depreciations are statistically significant.

\footnotetext{
${ }^{6}$ The output gap is derived by taking the deviations of the $\log$ of real GDP (approximated by the industrial production index) from the series smoothed by the Hodrick-Prescott filter.
} 
Figure III.9. Armenia: Impulse Responses of Import Prices to NEER Shocks Response to Cholesky One S.D. Innovations \pm 2 S.E.
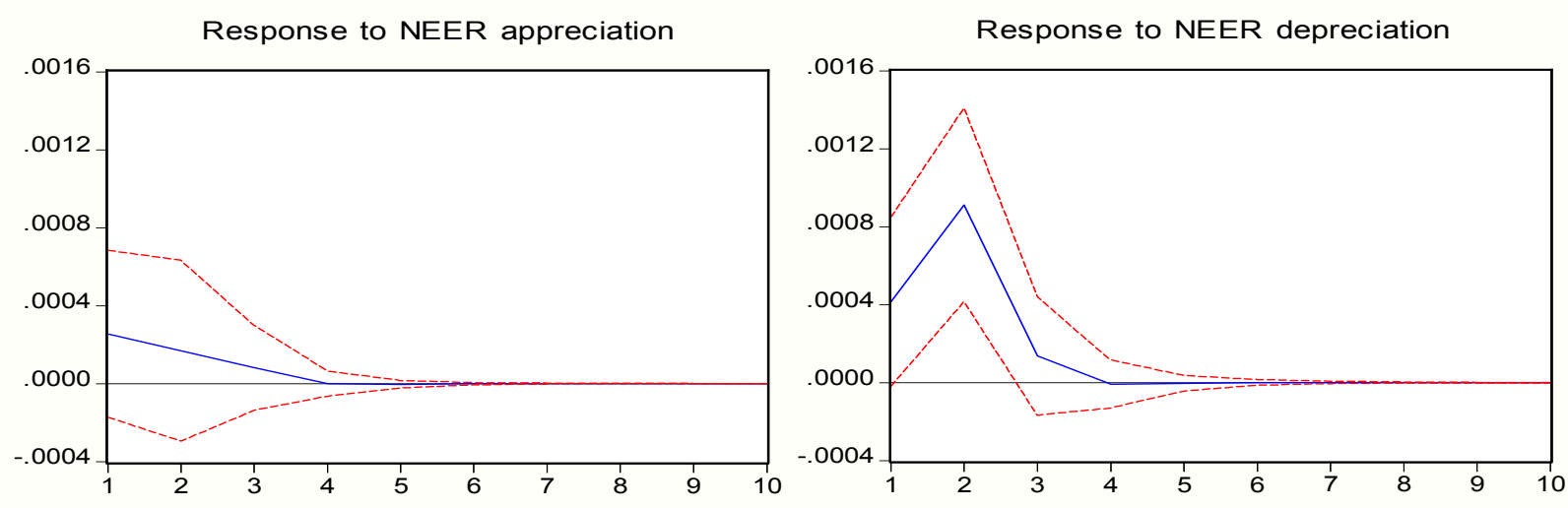

24. The other main finding is that the exchange rate pass-through is much larger (about three times) for depreciations than for appreciations (Figures III.10 and III.11). In terms of speed, the adjustment in import prices to both appreciations and depreciations last about 3 months.

Figure III.10. Armenia: Exchange Rate Pass-through to Import Prices

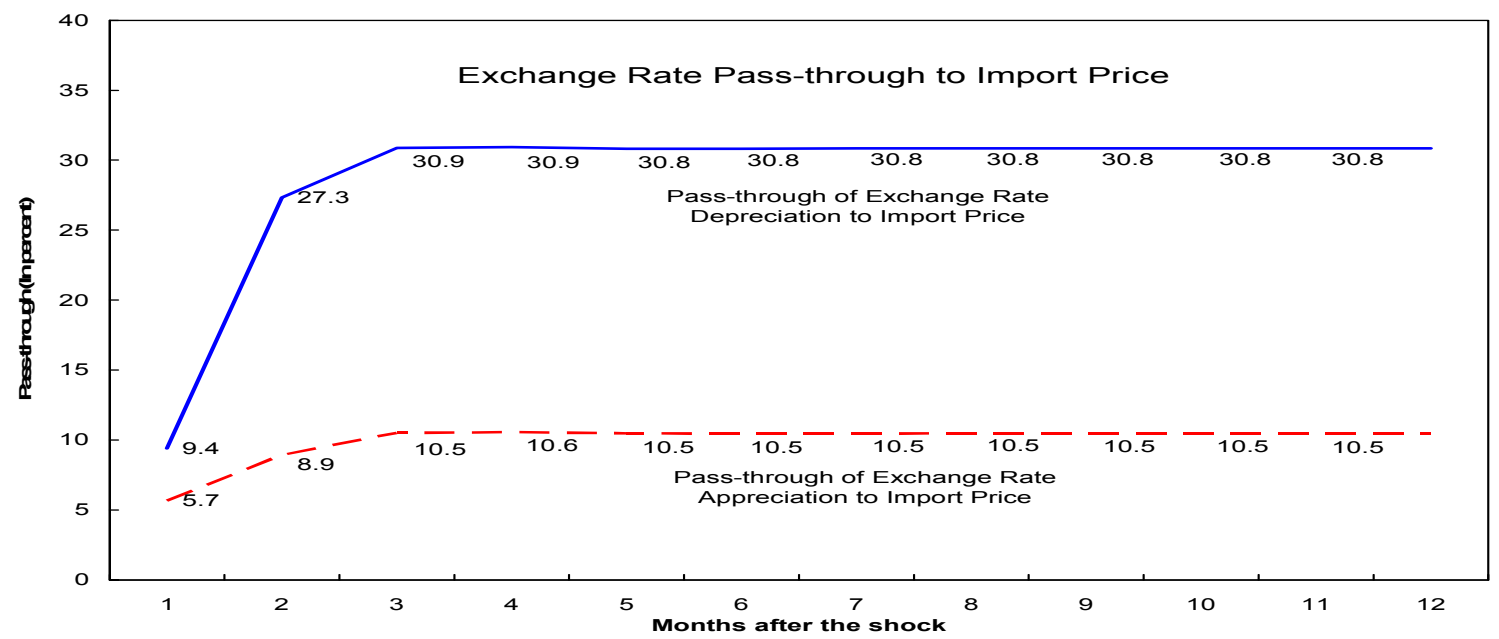


Figure III.11. Armenia: Speed of Exchange Rate Pass-through to Import Prices

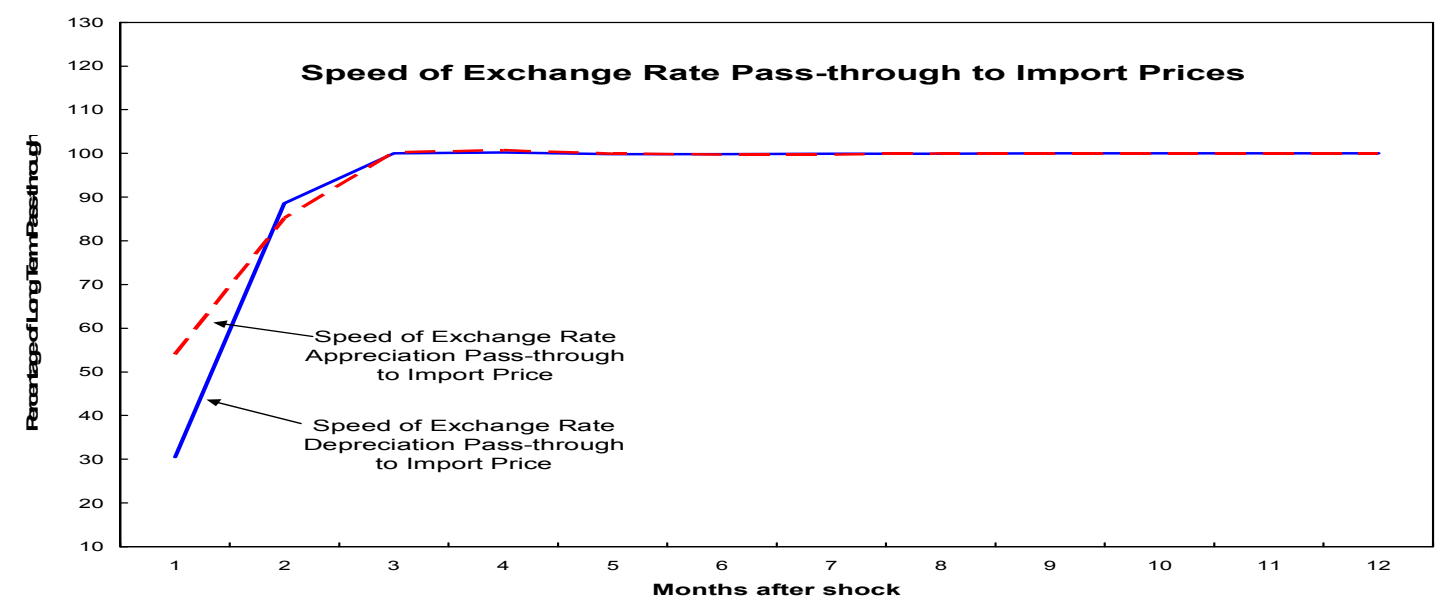

25. The asymmetric pass-through underlying the estimates suggests that there is significant downward rigidity in import prices in response to exchange rate movements. It is highly unlikely that this can be explained by transportation costs only, pointing instead to monopolistic practices in the import sector, which have limited the role of dram appreciation in containing inflationary pressures.

\section{E. Structural Competitiveness}

26. With the prospect of continued exchange rate appreciation over the medium term, improving competitiveness will require sustained improvements in productivity. To a large extent, this could be achieved by significantly improving the business environment.

27. While recent trends suggest moderate improvements in the ease of doing business, Armenia's performance remains weaker than that of a number of comparator countries in the region. Although progress has been made with improving the ease of getting credit, Armenia continues to rank poorly in terms of cross border trade and paying taxes. This outcome highlights the need for Armenia to accelerate the pace of tax administration reforms.

Table III.1. Selected Countries Rankings in the Buisness Enviroment Database (2006-08)

\begin{tabular}{|c|c|c|c|c|c|c|c|c|c|c|c|c|}
\hline & \multicolumn{3}{|c|}{$\begin{array}{c}\text { Ease of Doing Business Rank } \\
\text { Overall }\end{array}$} & \multicolumn{3}{|c|}{ Getting Credit } & \multicolumn{3}{|c|}{ Paying Taxes } & \multicolumn{3}{|c|}{ Trading Across Borders } \\
\hline & 2006 & 2007 & 2008 & 2006 & 2007 & 2008 & 2006 & 2007 & 2008 & 2006 & 2007 & 2008 \\
\hline Armenia & 34 & 46 & 39 & 65 & 62 & 36 & 148 & 137 & 143 & 119 & 133 & 118 \\
\hline Georgia & 37 & 35 & 18 & 48 & 62 & 48 & 104 & 103 & 102 & 95 & 59 & 64 \\
\hline Azerbaijan & 99 & 97 & 96 & 21 & 21 & 26 & 136 & 142 & 141 & 158 & 170 & 173 \\
\hline Latvia & 24 & 20 & 22 & 13 & 12 & 13 & 52 & 38 & 20 & 28 & 22 & 19 \\
\hline Lithuania & 16 & 24 & 26 & 33 & 32 & 36 & 40 & 74 & 71 & 32 & 23 & 23 \\
\hline Estonia & 17 & 18 & 17 & 48 & 45 & 48 & 29 & 32 & 31 & 6 & 7 & 7 \\
\hline Ukraine & 128 & 139 & 139 & 65 & 62 & 68 & 174 & 177 & 177 & 106 & 116 & 120 \\
\hline
\end{tabular}

Source: World Bank. 
28. Armenia's global competitiveness rankings also lag behind that of comparable countries in the region. Armenia is ranked at 93 far above Latvia, Estonia, and Lithuania. Armenia scores poorly on infrastructure, institutions, and financial market sophistication. Given the weak and highly concentrated export base, significant strides are needed in structural reforms to boost competitiveness.

Table III.2. Global Competitiveness Index Ranking and Score, 2007-2008 1/

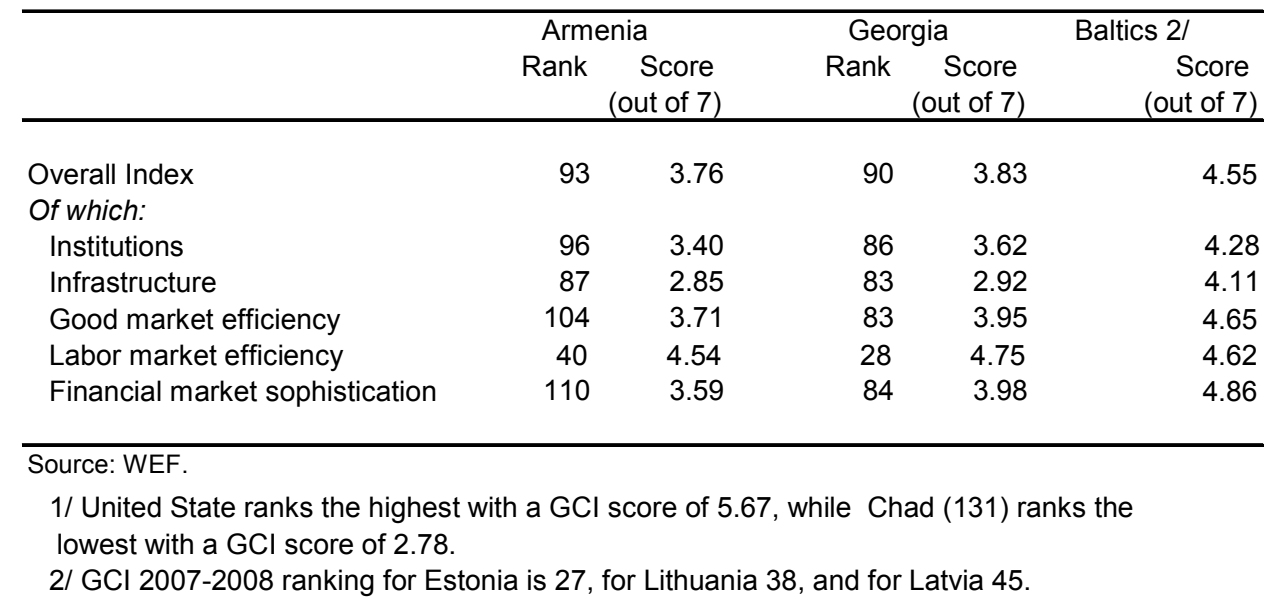

\section{F. Conclusions}

29. The recent dramatic appreciation of the dram has removed the previously existing undervaluation, bringing the real exchange rate near or possibly slightly above equilibrium. This finding was consistent across the differing methods used to evaluate the degree of exchange rate misalignment. Meanwhile, pass-through estimates suggest that there is significant downward rigidity in import prices in response to exchange rate movements.

30. Safeguarding competitiveness in the context of dramatic dram appreciation calls for a more determined approach to structural reforms so as to improve the business environment, raise productivity, and contain inflationary pressures. Securing productivity gains will require improving tax and customs administration, deepening financial intermediation, reducing corruption, and discontinuing monopolistic practices in the import sector. 


\section{REFERENCES}

Balassa, Bela, 1964, “The Purchasing Power Parity Doctrine: A Reappraisal,” Journal of Political Economy, Vol. 72, No. 6, pp. 584-96.

Coricelli, Fabrizio, and Bostjan Jazbec, 2001, "Real Exchange Rate Dynamics in Transition Economies," CEPR Discussion Paper, No. 2869 (July).

De Broeck, Mark, and Torsten Sløk, 2001, “Interpreting Real Exchange Rate Movements in Transition Countries," IMF Working Paper 01/56 (Washington: International Monetary Fund).

Égert, Balazs, 2003, “Assessing Equilibrium Exchange Rates in CEE Acceding Countries: Can We Have DEER with BEER without FEER? A Critical Survey of the Literature," Focus on Transition, Vol. 2, pp. 38-106.

IMF, 2008, "Exchange Rate Assessment," draft, Middle East and Central Asia Department, (Washington: International Monetary Fund).

McCarthy, Jonatahan, 2007, "Pass-Through of Exchange Rates and Import Prices to Domestic Inflation in some Industrialized Economies," Eastern Economic Journal, Vol. 33, No. 4 (Fall), pp. 511-37.

Oomes, Nienke, Fernando Gonçalves, and Gohar Minasyan, 2008, "Dealing With Dramatic Appreciation: Is the Armenian Dram Still Competitive?” IMF Working Paper (forthcoming) (Washington: International Monetary Fund).

Rogoff, Kenneth, 1996, “The Purchasing Power Puzzle," Journal of Economic Literature, Vol. 34, No. 2 (June), pp. 647-68.

Samuelson, Paul A., 1964, "Theoretical Notes on Trade Problems," Review of Economics and Statistics, Vol. 46, No. 2, pp. 145-54. 